\title{
Benthic foraminifera: indicators for a long-term improvement of living conditions in the Late Valanginian of the NW German Basin
}

\author{
CHRISTIAN KLEIN \& JÖRG MUTTERLOSE \\ Institut für Geologie, Mineralogie und Geophysik, Universitätsstr. 150, Ruhr-Universität Bochum, 44801 Bochum, Germany. \\ (e-mail: Christian.Klein@ruhr-uni-bochum.de; Joerg.Mutterlose@ruhr-uni-bochum.de)
}

\begin{abstract}
Foraminiferal occurrences in marine sediments of Late Valanginian age (Early Cretaceous) are described from NW Germany. The distribution patterns of benthic foraminifera are discussed with respect to their abundance and diversity. Benthic foraminifera are characterized in terms of moderate diversity and abundance. Vertical fluctuations in foraminifera contents are discussed with respect to their palaeoecology and palaeobiogeography. Benthic foraminifera, which are represented by a total of 101 species, show a gradual increase of diversity throughout the Late Valanginian. This improvement of living conditions in an epicontinental sea over a period of approximately 2 million years indicates a gradual recolonization of the formerly non-marine semi-restricted basin. The associations are dominated by agglutinated taxa with common Ammobaculites, Ammovertella, Bulbobaculites, Haplophragmoides, Proteonina, Psammosphaera and Reophax. The calcareous species Epistomina caracolla, which is extremely common in certain intervals, may reach significant abundances. Further agglutinated and calcareous taxa occur rarely. The early Late Valanginian is marked by the occurrence of the Tethyan species Cerobertinella subhercynica, reflecting a major sea-level highstand. J. Micropalaeontol. 20(1): 81-95, July 2001.
\end{abstract}

\section{INTRODUCTION}

Early studies dealing with earliest Cretaceous benthic foraminifera from NW Germany concentrated mainly on stratigraphic and taxonomic aspects (e.g. Bartenstein \& Brand, 1951; Bartenstein \& Bettenstaedt, 1962). It is only in the late 1980s and early 1990s that interest in benthic foraminifera of the Valanginian of this area was revitalized by studies of Niedziolka (1988) on stratigraphic aspects and by Meyn \& Vespermann (1994) on taxonomic problems. The only study which covers palaeoecological and sequence stratigraphical aspects was published by Stadtler (1998) and concentrates on the Early Valanginian Bentheim Sandstone and its sequence stratigraphic interpretation. The most recent account of Valanginian foraminifera has been presented by Mutterlose et al. (2000). No attempt has hitherto been made to understand benthic foraminifera from the palaeoecological-palaeogeographical point of view. During the last fifteen years extensive sampling of Lower Cretaceous sediments from outcrops in northern Germany has been performed.

For the current study fifty-four samples derived from four outcrops were analysed qualitatively and quantitatively. Abundance fluctuation of various taxa is discussed with respect to its palaeoecological context in order to decipher the role of autoecological factors on the composition of foraminiferal assemblages. Variations of diversity and abundance of benthic foraminifera are clearly controlled by palaeoceanographic changes on a regional scale. Thus these shifts in marine communities are here used to reconstruct the Valanginian Boreal sea.

\section{GEOLOGICAL BACKGROUND}

\section{Palaeogeography of the NW German Basin}

In Early Cretaceous times the NW German Basin (NWGB) formed the southernmost extension of the North Sea Basin, which itself was the southernmost extension of the Boreal-
Arctic sea. Due to its palaeogeographical position between the Tethys and the Boreal Realm the NWGB and the adjoining proto-North Sea Basin formed an important marine passage for marine biota. Apart from this northward-directed seaway which existed throughout Valanginian-Albian times, the NWGB also had connections via seaways to the Tethys in the south. These were less stable than those to the north and were interrupted during regressive periods in Berriasian and Barremian/Early Aptian times.

The NWGB was about $280 \mathrm{~km}$ long and $80 \mathrm{~km}$ wide. More than $2000 \mathrm{~m}$ of Lower Cretaceous sediments accumulated in this epeirogenic basin. Lithological changes and different sediment accummulation rates within the basin allow for a differentiation of a western part (area Rheine-Bentheim-Meppen-Groningen), a central part (area Osnabrück-Bielefeld-Minden-Vechta) and an eastern part (area Hannover-Braunschweig-Salzgitter) (Schott et al., 1967/1969).

Marine sediments of Valanginian age are widespread in a $50 \mathrm{~km}$ wide belt from Bentheim in the west up to the Hannover/ Braunschweig area in the east. These sediments show a clear lithological variation. Dark shales and mudstones with a low $\mathrm{CaCO}_{3}$ content and abundant sideritic nodules represent the basin-facies. High subsidence and accumulation rates went along with a low oxygen-content.

\section{MATERIAL AND METHODS}

Fieldwork was performed from 1984 to 1999. All existing clay pits with known Valanginan strata were logged lithologically and sampled subsequently for micropalaeontological studies. In addition, macrofossils were collected bed-by-bed to allow for detailed biostratigraphic zonation based on ammonites. Macrofossils were also used to indicate changes in the provenance of marine biota, in particular to date the timing and influx of tethyan-derived ammonite faunas. Material from four clay pits (Twiehausen, Hollwede, Varlheide, Diepenau), situated in the 


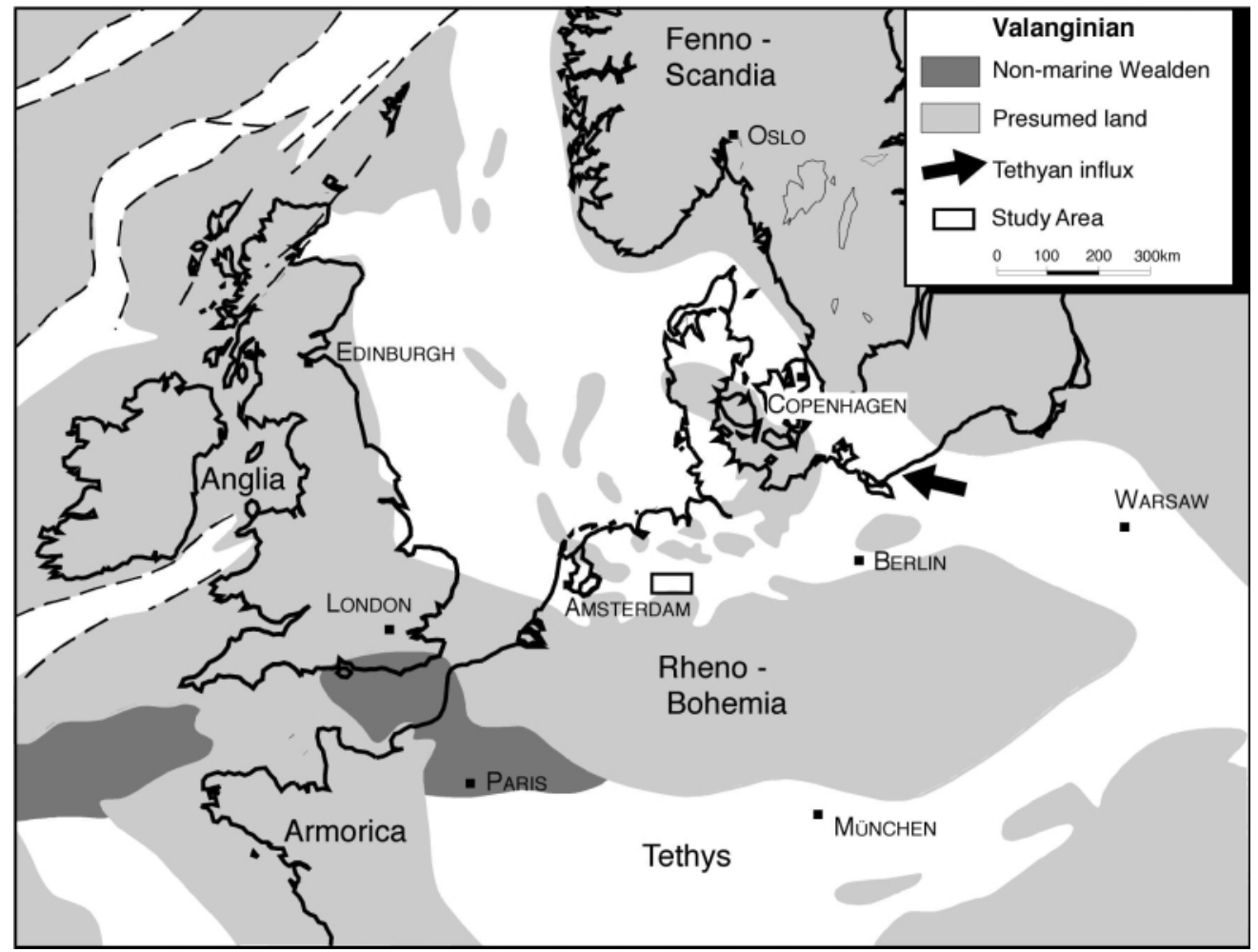

Fig. 1. Palaeogeographical map for the Valanginian of northwestern Europe, showing the studied area.

northern part of North Rhine Westphalia was considered for this study (Fig. 1). A detailed description of the lithology, biostratigraphy and faunal contents of these sites is given by Mutterlose (1992) and Mutterlose et al. (2000). Apart from Twiehausen, mining has been stopped in these pits and the outcrop conditions of these abandoned pits is extremely poor. A total of 74 samples were collected bed-by-bed and, subsequently, 54 of these samples were investigated for foraminifers.

For the foraminferal investigation different amounts of dried sediment samples were processed with tenside (REWOQUAT ${ }^{\mathbb{R}}$ W 3690 PG), since the standard hydrogen peroxide method proved to be ineffective. The weight of the processed samples varied from $120-400 \mathrm{~g}$ for sample. After crushing, the raw material was covered with a tenside/ethanol mixture. Several times a week the sample was stirred up and after one or two weeks it was washed through a $200 \mu \mathrm{m}$ and a $63 \mu \mathrm{m}$ sieve. The dry insoluble residue was weighed and subtracted from the original weight of the sample. After drying and weighing the sieved material was divided into three fractions $(>315 \mu \mathrm{m}$, $200-315 \mu \mathrm{m}$ and $<200 \mu \mathrm{m})$. The two large fractions ( $>315$ and 200-315 $\mu \mathrm{m})$ were picked completely. Occasionally, foraminiferal abundances in these fractions were extremely high, requiring splits to be made (Brolsma, 1978). These were obtained by using the classical method. A minimum of 300 individuals was picked for each sample. The finest fraction $(<200 \mu \mathrm{m})$ was only picked quantitatively and is not considered in the absolute counts.

All specimens, which were picked from the two large fractions, were counted. Only few taxa attain abundances higher than $1 \%$. These were chosen for a more detailed discussion of the palaeoenvironment. A complete list of all foraminifera encountered is given in the taxonomix index (Appendix A). Relative abundances are given by using the following abbreviations: very common (VC: $>20 \%$ ); common (C: $19.9-5 \%$ ); rare (R: 4.9-1\%); very rare (VR $<0.9 \%$ ), see Appendix $\mathrm{B}$. The numbers of specimens, as discussed in the text, is always based on $200 \mathrm{~g}$ raw material. The abbreviation $\mathrm{AF}$ is used for agglutinated foraminifera and $\mathrm{CF}$ for calcareous foraminifera.

The generic classification used here is based on Loeblich \& Tappan (1987), the classification at species level follows Bartenstein \& Brand (1951) and Meyn \& Vespermann (1994). SEM photographs were taken on a LEO 1530, all specimens and samples are located at the Institut für Geologie, Mineralogie und Geophysik of the Ruhr-Universität Bochum. The $\mathrm{CaCO}_{3}$ content of the samples was measured on an AAS (AtomicAbsorption-Spectrometer), the organic carbon (TOC) content on a coulometer.

\section{LOCATIONS AND STRATIGRAPHY}

The four investigated sections (Twiehausen, Hollwede, Varlheide, Diepenau) are located in the western part of NW Germany, north of the Wiehengebirge approximately $20 \mathrm{~km}$ west of Minden (Fig. 1). Detailed descriptions of their lithology, biostratigraphy and faunal content is given by Mutterlose (1992) and Mutterlose et al. (2000).

The $32 \mathrm{~m}$ thick succession of the Twiehausen section [grid reference R: 34 67080, H: 58 07400] is of early Late Valanginian age (Prodichotomites hollwedensis ammonite zone and lower part of the Prodichotomites polytomus ammonite zone; Fig. 2). The succession is well known for its rich and diverse ammonite 
Valanginian benthic foraminifera

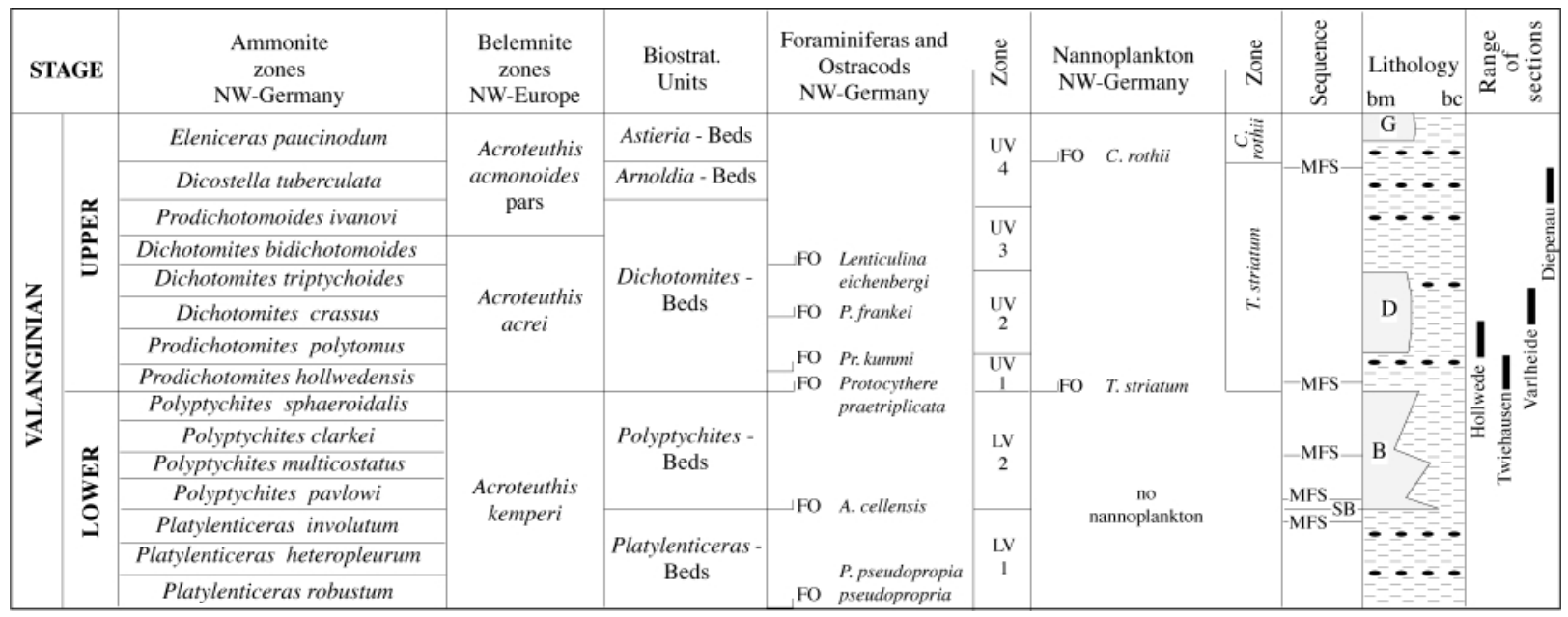

Fig. 2. Stratigraphic range of the studied sections. FO, first occurrence; LV, Lower Valanginian; UV, Upper Valanginian; MFS, maximum flooding surface; SB, sequence boundary; bm, basin margin; bc, basin centre; B, Bentheim Sandstone; D, Dichotomites Sandstone; G, Grenz Sandstone. Foraminifera and Ostracods: P, Protocythere; Pr, Protomarssonella; A, Ammovertella. Nannoplankton: C, Conusphaera; T, Tegementum.

faunas (Kemper et al., 1981; Mutterlose, 1992; Mutterlose et al., 2000). Apart from boreal taxa several tethyan-derived ammonites have been described from this section, which consists of $\mathrm{CaCO}_{3}$ - and TOC-poor dark claystones.

The Hollwede pit [grid reference R: 34 65950, H: 58 07500] exposed $7 \mathrm{~m}$ of Upper Valanginian claystones (Prodichotomites polytomus ammonite zone; Fig. 2). The boreal ammonite faunas of this clay pit were described by Kemper (1978), Kemper et al. (1981) and Jeletzky \& Kemper (1988). Tethyan ammonites recorded from Hollwede were derived from the underlying $P$. hollwedensis zone, which was no longer accessible when the fieldwork was carried out for the current study. The $\mathrm{CaCO}_{3}$ content varies from $1.2 \%$ (sample 99/3) to $8.3 \%$ (sample 101/1), the TOC contents from $0.2 \%$ (sample 101/1) to $0.7 \%$ (sample 97/2).

A $12 \mathrm{~m}$ thick succession of claystones of mid-Late Valanginian age (upper part of the Dichotomites crassus ammonite zone; Fig. 2) was exposed in the Varlheide pit [grid reference R: 34 70875, H: 58 06875]. Diverse boreal ammonites assemblages, yielding minor tethyan influences are known from Varlheide (Seitz, 1950; Kemper, 1978; Rawson \& Kemper, 1978; Kemper et al., 1981). The $\mathrm{CaCO}_{3}$ content varies from 3\% (sample 93/2) to $13 \%$ (sample 109/1).

The Diepenau pit [grid reference R: 34 80700, H: 58 08670] covers a $5 \mathrm{~m}$ thick claystone sequence of latest Valanginian age (Dichotomites tuberculata ammonite zone; Fig. 2). Diverse tethyan and boreal ammonite assemblages have been figured from Diepenau (Seitz, 1950; Kemper, 1978; Kemper et al., 1981; Mutterlose, 1992). The $\mathrm{CaCO}_{3}$ content varies from 2\% (sample $93 / 1$ ) to $6 \%$ (sample $99 / 1$ ).

\section{BENTHIC FORAMINIFERA}

The distribution patterns of benthic foraminifera (Figs 3-6) are discussed in the order of the stratigraphic succession. Following the ammonite zonation schemes, typical assemblages of foraminifera (see Plates 1 and 2) are described for each outcrop.
These assemblages are discussed with respect to palaeoenvironmental aspects.

\section{The earliest Late Valanginian assemblage (A1)}

These foraminiferal assemblages are dominated by agglutinated taxa including Ammobaculites agglutinans, Ammovertella cellensis, Bulbobaculites inconstans erectum, Haplophragmoides spp., Proteonina difflugiformis, Psammosphaera fusca and Reophax scorpiurus (Figs 7, 8). Epistomina caracolla is the only calcareous taxon which occurs in large numbers, up to $22 \%$ (sample 93/2). Additional, less common taxa of agglutinated and calcareous foraminifera have been observed. A total of 23 agglutinated and 34 calcareous taxa have been found. Sample $95 / 1$ is marked by a diverse fauna consisting of 29 taxa. It is only in this sample that Cerobertinella subhercynica was observed (4 individuals). This decrease of diversity is caused by changes in the composition of calcareous taxa which vary from $0-16$ species per sample. In the lower part of the succession (samples 71-101) diversity is significantly higher than in the upper part (samples 103-119). This is clearly reflected by the AF/CF ratio. Calcareous foraminifera, which have a ratio from $0-35 \%$ attain a significant maximum in the middle part of the section (samples 91/1-101/1).

The abundance patterns show three maxima (samples 71-75, 85-89, 111-119). Abundance increases from 1900 specimens (sample 75/1) to 3200 specimens (sample 85/4) and to a maximum of 8500 specimens (sample 119/1). All three parameters (diversity, AF/CF ratio, abundance) show a similar trend that may reflect environmental changes. This shift marks the base of the $P$. polytomus zone and may be used as a biostratigraphic marker in the future.

A. cellensis, a common index species of the lower Upper Valanginian, is present in all samples, except for samples 115-119. Samples $85 / 1$ to $89 / 4$ show a distinctive maximum of A. cellensis (sample 89/2, 1174 specimens). In this sample $A$. cellensis represents $47.2 \%$ of all specimens encountered. A second peak is visible in the upper part of the section (samples 


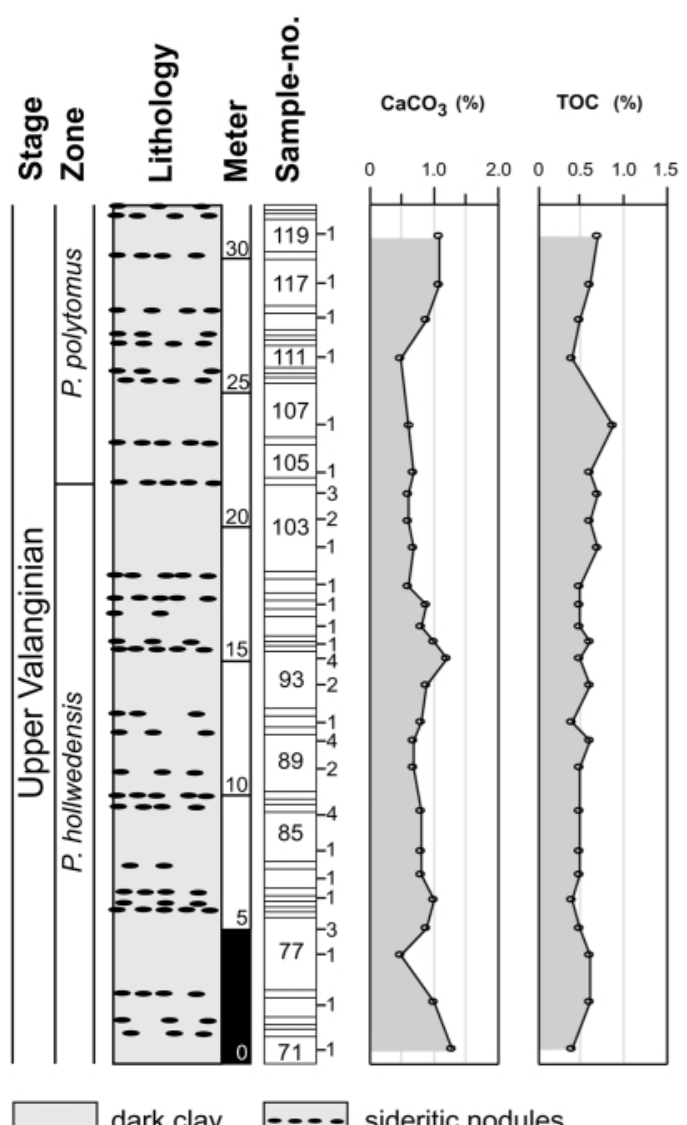

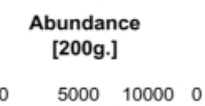

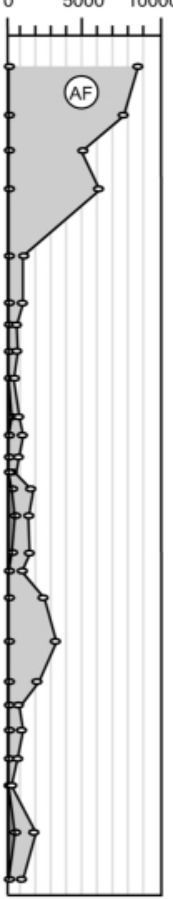

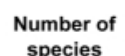

species

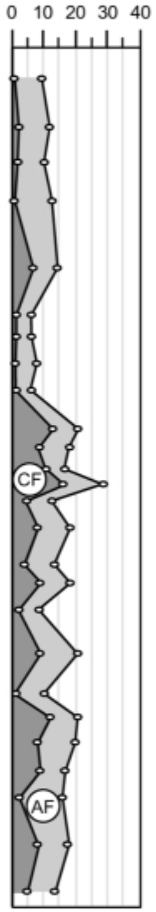

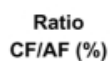

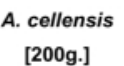

P. fusca

[200g.]

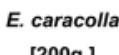

0
0 $100 \quad 0$
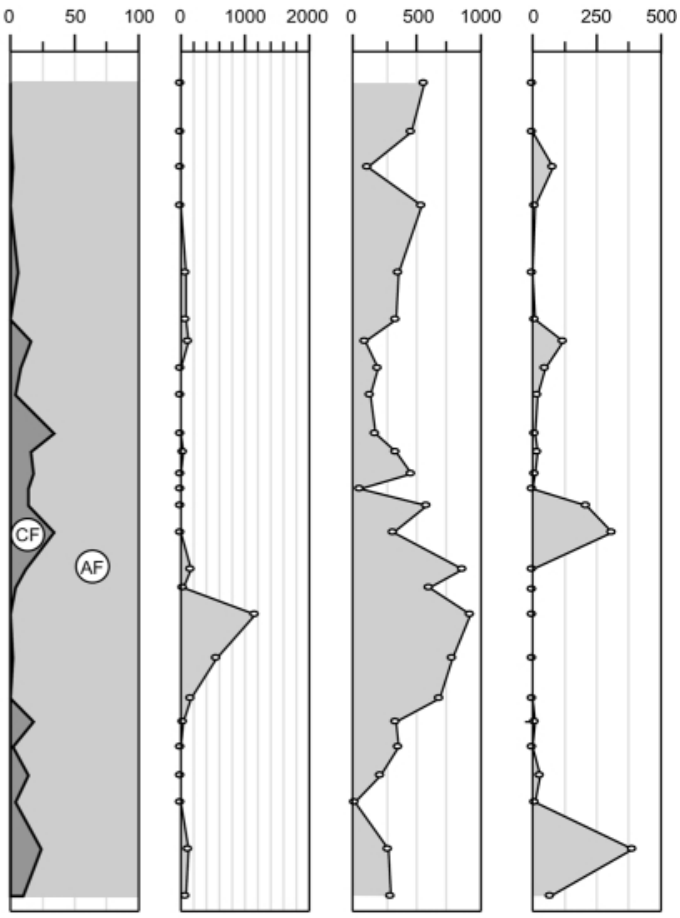

Fig. 3. Fluctuations in the benthic foraminiferal content of the Twiehausen section (A1) on a high resolution scale. Ammonites: P., Prodichotomites. Foraminifera: A., Ammovertella; P., Psammosphaera; E., Epistomina. CF, calcareous foraminifera; AF, agglutinated foraminifera.

103, 107). In sample $103 / 3$ A. cellensis represents $19.8 \%$ of all specimens.

Psammosphaera fusca, another common species, dominates the assemblages throughout the succession. This species attains more than $50 \%$ of the whole foraminiferal assemblage in samples 89/4, 91/1 and 97/1.

The only common calcareous species is E. caracolla with a maximum of 390 specimens (sample $75 / 1,22 \%$ of all individuals). Samples 75, 93103 and 115 are characterized by $E$. caracolla peaks, with a general increase of this species towards the top of the succession.

The early Late Valanginian assemblage (A2)

Most common foraminifera of this assemblage include $A$. agglutinans, Ammobaculites irregulariformis, Bulbobaculites inconstans inconstans, E. caracolla, E. ornata, Lenticulina muensteri, $P$. difflugiformis and $R$. scorpiurus (Figs 7, 8). These species are associated with additional taxa of agglutinated and calcareous foraminifera which are, however, less common. Twenty-four taxa of agglutinated and 24 calcareous taxa were observed in the 9 samples investigated from this interval.

Diversity varies insignificantly from 18 (sample 95/1) to 27 (samples 97/1, 101/1). Diversity of agglutinated taxa is rather stable (10-16 taxa), while it varies considerably for calcareous taxa (3-14 taxa). The $\mathrm{AC} / \mathrm{CF}$ ratio ranges from $0.8 \%$ (sample 99/3) to $84 \%$ (sample 99/3), showing three maxima for calcareous forams (samples 95/2, 99/1 and 101/1). The ratio of calcareous foraminifera always exceeds $65 \%$.

Abundance varies considerably, with two maxima recognizable (sample 95/1, 10000 specimens; samples 99/2 and 99/3, 6000 specimens). The lowest abundances were observed in the middle of the section (sample 99/1, 1300 specimens). The maxima have a positive correlation with agglutinated foraminifera. The high abundance in sample $95 / 2$ is caused by an acme of E. caracolla; 4652 of a total of 7466 foraminifera were attributed to this species. Diversity of foraminifera shows a uniform pattern.

Both E. caracolla and E. ornata are common throughout the interval. E. caracolla is present in all samples with the number of specimens varying from 19 (sample 99/3) to 4652 (sample $95 / 2$ ). The species has its maximum in the lower part of the section (sample 95/2), though it is also common near the top of the section (sample 101/1, 402 individuals $=26.7 \%$ of all foraminifers). Remarkable is the occurrence of $E$. ornata, since it is the earliest recorded occurrence in the NWGB. E. ornata has a maximum in the middle part of the section (sample 99/1, 429 specimens). Samples 95/1, 99/3 and 103/1 did not yield $E$. ornata, which is always less frequent than $E$. caracolla. 


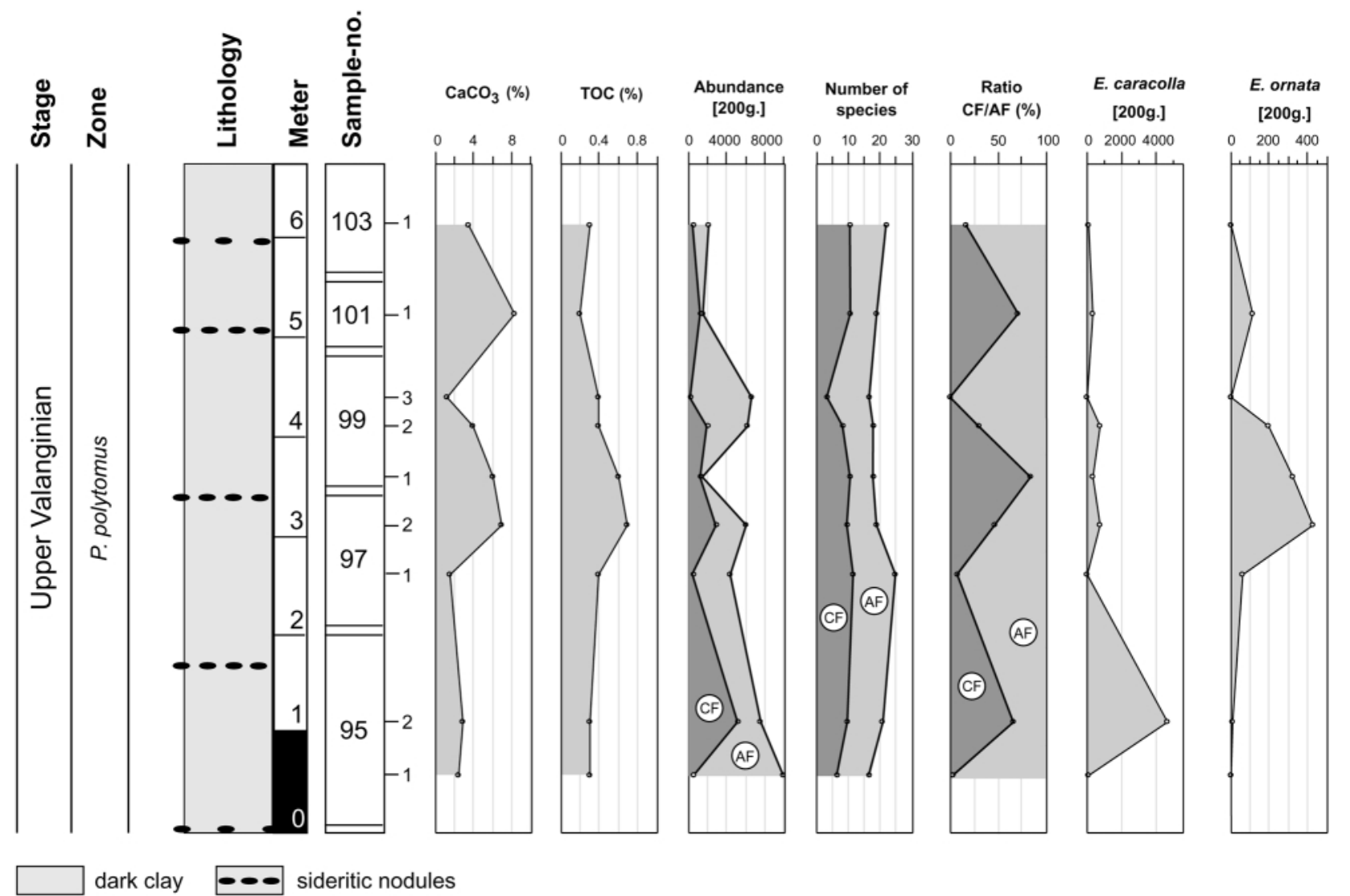

Fig. 4. Fluctuations in the benthic foraminiferal content of the Hollwede section (A2) on a high resolution scale. Ammonites: P., Prodichotomites. Foraminifera: E., Epistomina. CF, calcareous foraminifera; AF, agglutinated foraminifera.

The mid-Late Valanginian assemblage (A3)

The most common species of this assemblage are A. agglutinans, A. irregulariformis, E. caracolla, L. muensteri and R. scorpiurus (Figs 7,8). In particular $A$. irregulariformis is extremely common in this interval and thus characterizes the assemblage. Additional taxa of agglutinated and calcareous foraminifera add up to a diverse fauna of 21 taxa of agglutinated and 39 calcareous taxa.

Diversity ranges from 16 species (sample 87/3) to 31 (sample 109/1) with fluctuations mainly caused by changes in the composition of calcareous foraminifera (varying from 2-19 taxa). Agglutinated foraminifera show a more stable distribution, with 9-15 taxa. Both diversity and the AC/CF ratio reach a maximum for calcareous foraminifera at the top of the section (sample 107/1, 91.9\%).

Abundance varies considerably from 305 (sample 87/1) to 3097 specimens (sample 89/1). Two maxima occur (samples 89/1-93/2, up to 3097 specimens; samples 99/3-101/1, up to 2572 specimens). A high percentage is represented by E. caracolla; e.g. in sample 99/3 E. caracolla represents 1811 out of 2307 specimens. Due to the common occurrence of $E$. caracolla the abundance of calcareous foraminifera is always higher than $50 \%$ except for sample $87 / 3(35.5 \%)$.

The distribution of E. caracolla is clearly reflected by the AC/CF ratio. There are two maxima (samples 89/1-93/2, 1510 and 1009 specimens; samples 99/3-103/1, 1029 and 1811 speci- mens). E. caracolla varies throughout the section from 140 (sample 87/1) to 1811 specimens (sample 99/3). The highest percentage of E. caracolla marks sample $107 / 1$ (86.5\%), the lowest sample $87 / 3(35.4 \%)$. All other calcareous foraminifera only occur in smaller numbers, varying from sample 87/3 (2 specimens $=0.13 \%$ ) to 121 ( sample $93 / 2=6 \%)$.

\section{The latest Valanginian assemblage (A4)}

Common foraminifera of this assemblage consist of the agglutinated species A. agglutinans, A. irregulariformis, $B$. subaequale and $R$. scorpiurus. Among calcareous foraminifera only E. caracolla and L. muensteri occur in higher numbers (Figs 7, 8). These foraminifera are associated with additional taxa, resulting in a total of 23 agglutinated and 37 calcareous taxa which have been been identified in the 8 samples of this interval.

Diversity varies from 22 species (sample 97/1) to 37 (sample 99/1), with higher values characterizing the upper part of the section. Diversity of calcareous foraminifera varies from 8 (sample 95/1) to 23 species (sample 101/1), while the diversity of agglutinated foraminifera is more constant. It fluctuates from 11 (sample 97/1) to 18 species (sample 99/1). The AC/CF ratio shows a dominance of agglutinated foraminifera, with two minor maxima for calcareous foraminifera; one at the base (sample 91/1, 32.2\%) and in the upper part (samples 97/1-103/1, 20-27.83). 
C. Klein \& J. Mutterlose

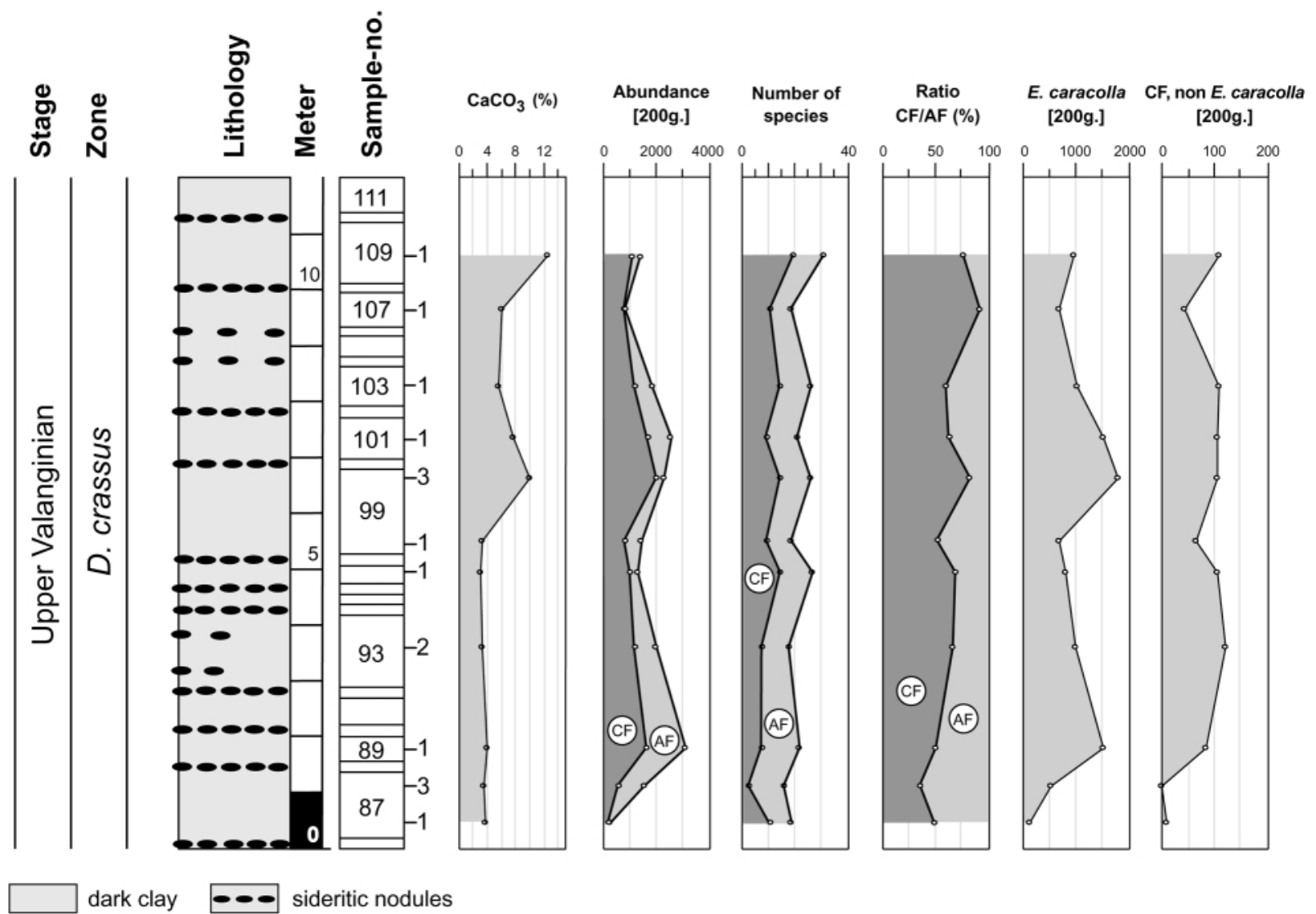

Fig. 5. Fluctuations in the benthic foraminiferal content of the Varlheide section (A3) on a high resolution scale. Ammonites: D., Dichotomites. Foraminifera: E., Epistomina. CF, calcareous foraminifera; AF, agglutinated foraminifera.

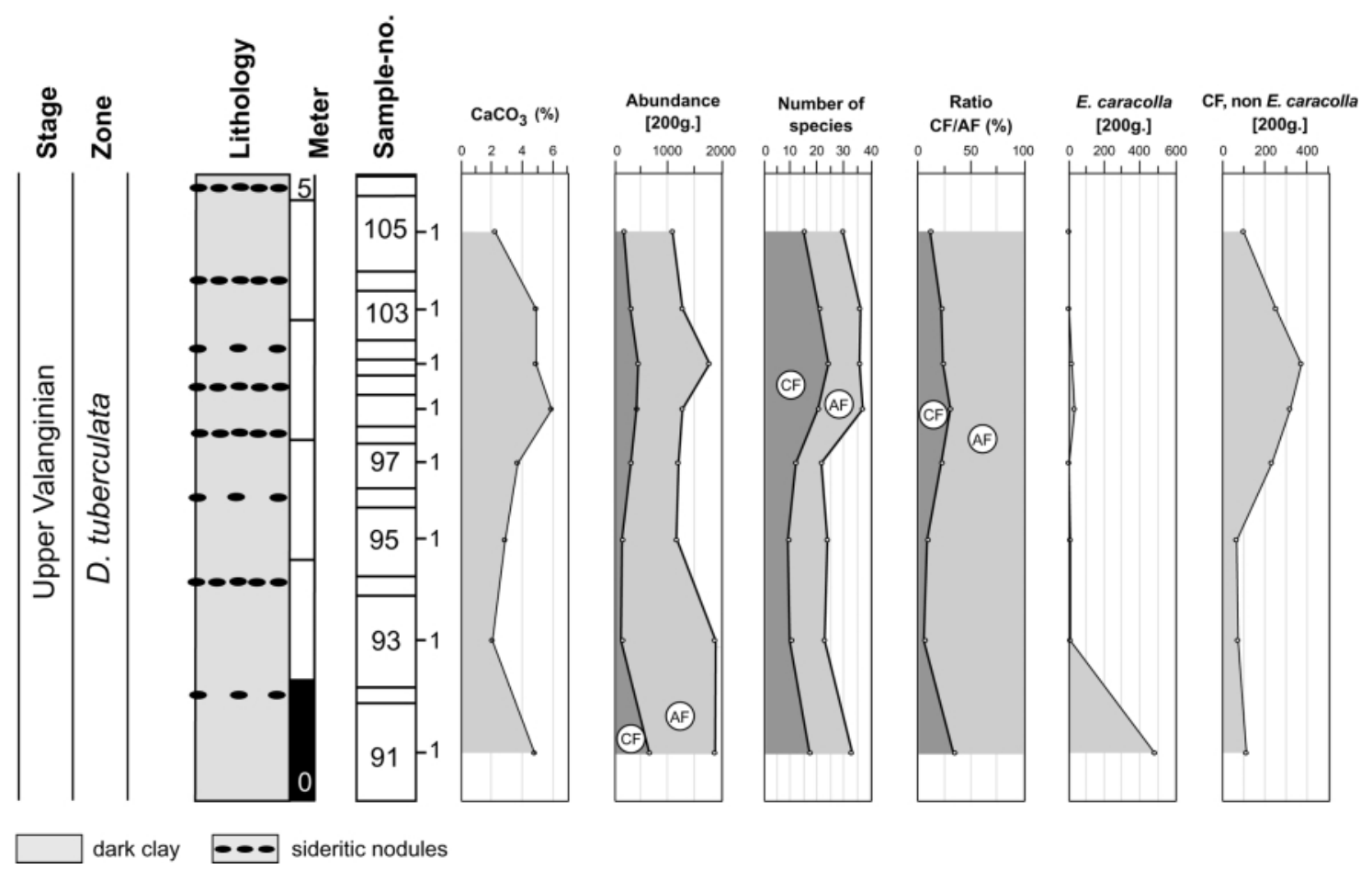

Fig. 6. Fluctuations in the benthic foraminiferal content of the Diepenau section (A4) on a high resolution scale. Ammonites: D., Dicostella. Foraminifera: E., Epistomina. CF, calcareous foraminifera; AF, agglutinated foraminifera. 
Valanginian benthic foraminifera

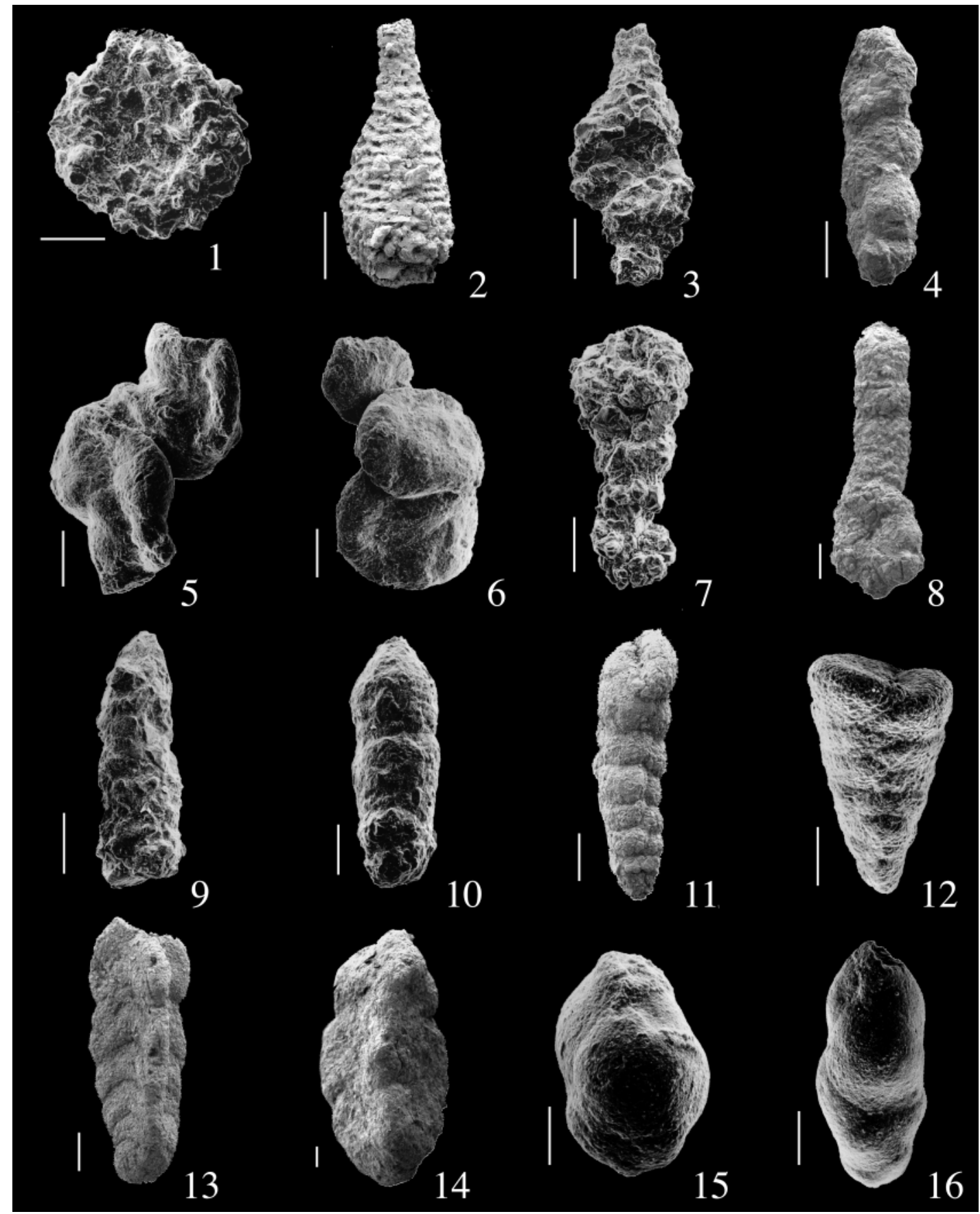

Explanation of Plate 1

Fig. 1. Psammospharea fusca, sample Tw 93/4/90. Scale bar=200 $\mu$ m. Fig. 2. Proteonina difflugiformis, sample Va 99/3/90. Scale bar=100 $\mu$ m. Fig. 3 . Reophax scorpiurus, sample Tw 93/2/90. Scale bar $=200 \mu \mathrm{m}$. Fig. 4. Gaudryinella hannoverana, sample Di 105/1/88. Scale bar=100 $\mu \mathrm{m}$. Figs 5-6. Ammovertella cellensis, sample TW 89/2/90. Scale bar=200 $\mu$ m. Fig. 7. Ammobaculites agglutinans, sample Hw 99/2/90. Scale bar=100 $\mu$ m. Fig. 8. Ammobaculites irregulariformis, sample Va 89/1/90. Scale bar $=200 \mu \mathrm{m}$. Fig. 9. Bulbobaculites inconstans inconstans, sample Hw 99/3/90. Scale bar $=200 \mu \mathrm{m}$. Fig. 10. Bulbobaculites inconstans erectum, sample Tw 99/1/90. Scale bar=200 $\mu \mathrm{m}$. Fig. 11. Verneuilinoides neocomiensis, sample Va 103/1/90. Scale bar $=100 \mu \mathrm{m}$. Fig. 12. Protomarssonella kummi, sample Hw 95/2/90. Scale bar $=100 \mu \mathrm{m}$. Fig. 13. Triplasia emslandensis emslandensis,

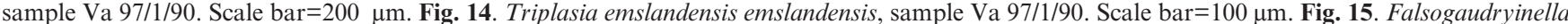
sp, sample Hw 97/2/90. Scale bar=50 $\mu$ m. Fig. 16. Falsogaudryinella sp, sample Hw 97/2/90. Scale bar=100 $\mu \mathrm{m}$.

Abundance varies only little from 1100 individuals (sample 105/1) to 1892 (sample 91/1). Abundance of calcareous foraminifera is high with 605 individuals (sample 91/1), domi- nated by 488 specimens of E. caracolla. Higher values exist again in the upper part of the section (samples 97/1-103/1) with 239393 individuals caused by increasing numbers of Lenticulina spp. 


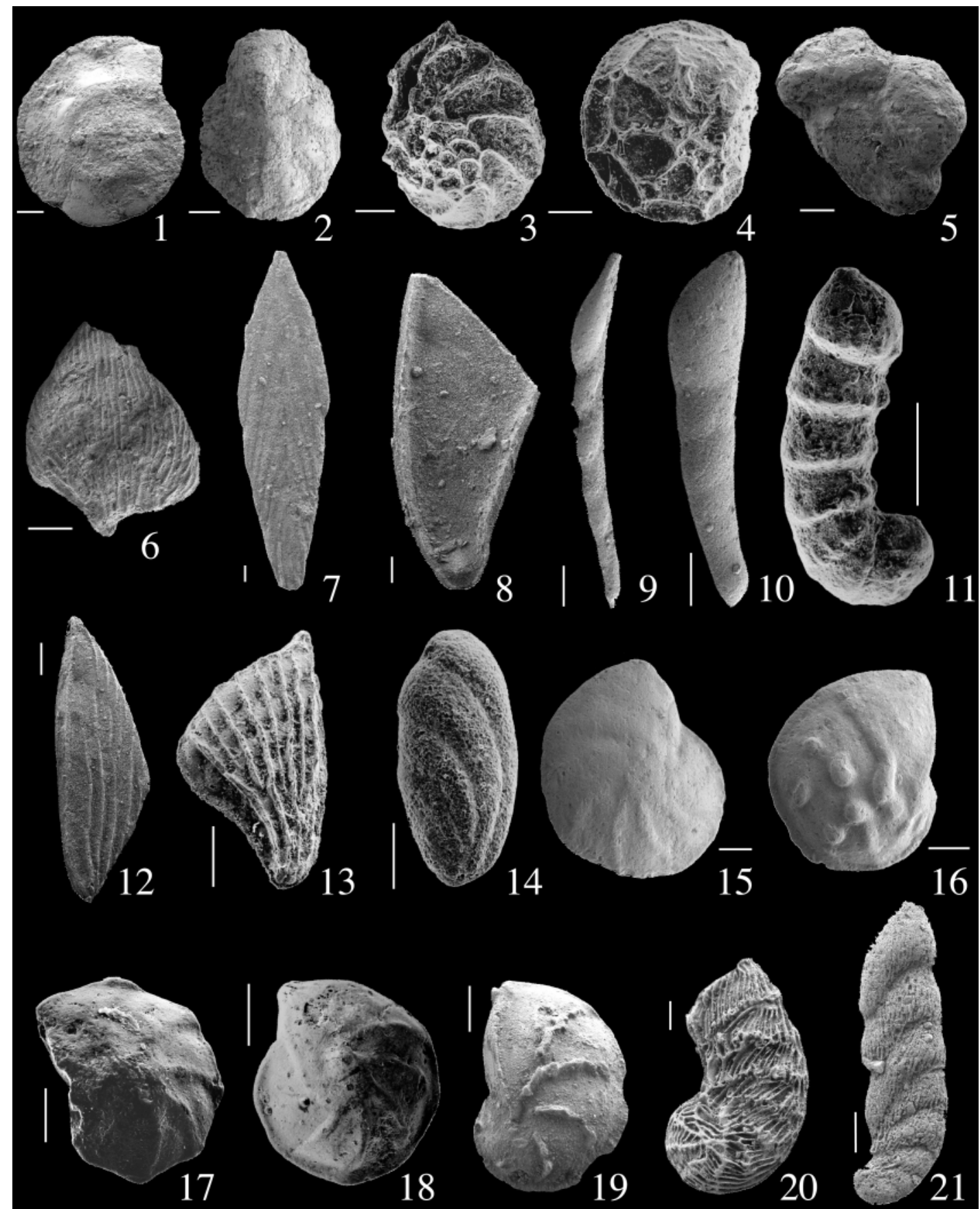

Explanation of Plate 2

Figs 1-2. Epistomina caracolla sample Di 95/1/88, scale bar $=100 \mu \mathrm{m}$; 1, spiral side; 2, umbilical side. Figs 3-4. Epsitomina ornata, sample HW 99/1/90, scale bar $=100 \mu \mathrm{m} ; 3$, spiral side; 4, umbilical side. Fig. 5. Hechtina praeantiqua, sample Di 99/1/88. Scale bar=100 $\mu$ m. Fig. 6. Frondicularia concinna, sample Di 103/1/88. Scale bar=200 $\mu \mathrm{m}$. Fig. 7. Frondicularia hastata, sample Va 109/1/90. Scale bar=100 $\mu$. Fig. 8. Psilocitharella kochi prolaevis,

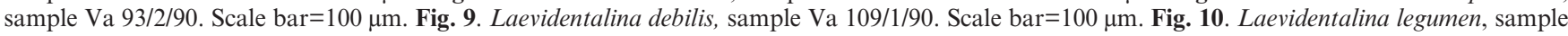
Di 103/1/88. Scale bar $=100 \mu \mathrm{m}$. Fig. 11. Marginulinopsis oldenburgensis, sample Tw 85/4/90. Scale bar=200 $\mu$ m. Fig. 12. Citharina discors discors, sample Va 103/1/90. Scale bar $=100 \mu \mathrm{m}$. Fig. 13. Citharina harpa, sample Tw 93/2/90. Scale bar $=200 \mu \mathrm{m}$. Fig. 14. Cerobertinella subhercynika, sample Tw 95/1/90. Scale bar=100 um. Fig. 15. Lenticulina muensteri, sample Di 97/1/88. Scale bar=100 $\mu$ m. Fig. 16. Lenticulina eichenbergi, sample Di 99/1/88. Scale bar $=100 \mu \mathrm{m}$. Fig. 17. Lenticulina nodosa, sample Hw 99/1/90. Scale bar=100 $\mu \mathrm{m}$. Fig. 18. Lenticulina roemeri, sample Hw 97/2/90. Scale bar $=200 \mu \mathrm{m}$. Fig. 19. Lenticulina saxonica, sample Va 97/1/90. Scale bar=100 $\mu \mathrm{m}$. Fig. 20. Vaginulinopsis reticulosa, sample Va 109/1/90. Scale bar $=100 \mu \mathrm{m}$. Fig. 21. Astacolus mutterlosei, sample Va 99/3/90. Scale bar $=100 \mu \mathrm{m}$. 


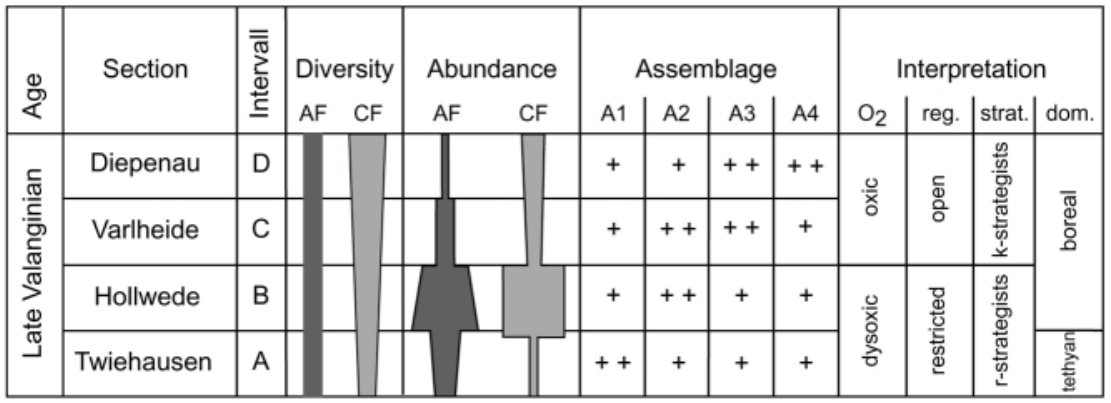

Fig. 7. Synthesis of micropalaeontological data from the late Valanginian of NW Germany. The intervals (A-D) are described in detail in the text. $\mathrm{AF}$, agglutinated foraminifera; $\mathrm{CF}$, calcareous foraminifera. reg., regime; strat., strategy; dom., domain.

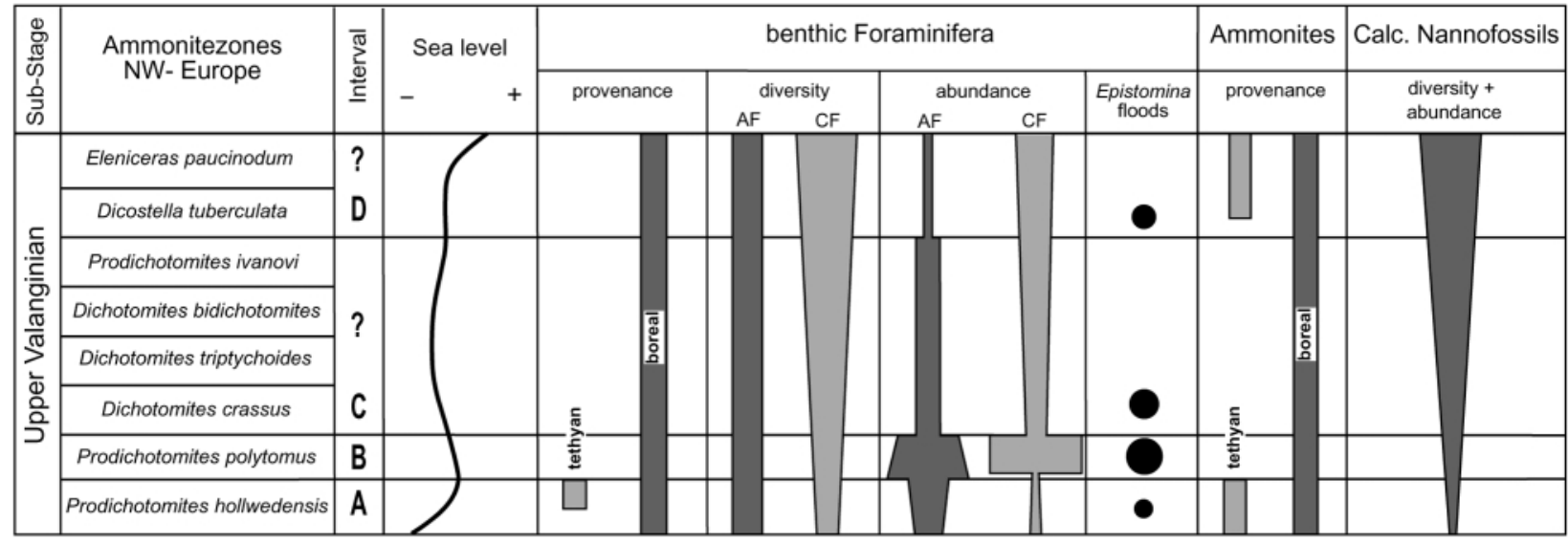

Fig. 8. Synthesis of distribution patterns of various groups of benthic foraminifera, ammonites and calcareous nannofossils for intervals A-D. AF, agglutinated foraminifera; $\mathrm{CF}$, calcareous foraminifera.

\section{Discussion}

The four Upper Valanginian intervals under discussion are characterized by assemblages of medium high diversity. A total of 101 taxa of benthic foraminifera have been identified out of which only 32 species are agglutinated and 69 are calcareous foraminifera. These abundances are significantly higher than those observed by Niedziolka (1988) who identified 73 species over the same interval from sections further east in the NWGB. This implies a higher diversity for the western part of the NWGB. On the other hand our data agree with the findings of Bartenstein \& Brand (1951), who identified 167 different taxa for the Upper Valanginian in several boreholes.

Ecological factors that control the abundance and diversity of benthic foraminifera include food availability (organic matter flux), temperature, substrate characteristics and oxygen content of bottom waters. In general, the benthic foraminifera have been used in the following ways as interpretative proxies.

- The highest total diversity and a high diversity of calcareous foraminifera is indicative of well oxygenated, shallow tropical to sub-tropical seas (Michael, 1974; Kemper, 1987; Murray, 1991).

- Associations of low diversity but high abundance are considered to be typical of an unstable environment, in particular low oxygen or low temperature conditions (Michael, 1979; Kemper, 1987; Kaminski et al., 1995).
- A dominance of simple agglutinated foraminifera (e.g. Psammosphaera spp., Trochammina spp., Haplophragmoides spp.) has been suggested to indicate cool water (Michael, 1979; Kemper, 1987). During the Cretaceous these forms are more common in the Boreal and deep-sea basins such as the Norwegian Sea and the Carpathian flysch.

- Cerobertinella subhercynica is considered to be a stenothermal warm water species, indicative of higher water temperatures (Vespermann, 1998). This assumption is based on the common occurrence of Cerobertinella in Tethyan warm water settings of Aptian and Albian age.

- Hechtina praeantiqua has been interpreted as a thermophile species (Michael, 1974, 1979). Furthermore, H. praeantiqua indicates areas with high oxygenation (Bartenstein \& Brand, 1951).

Results of this work can summarized as follows (Fig. 7). Diversity fluctuations throughout the four intervals are thought to reflect palaeoenvironmental changes of the bottom waters. After an earliest Late Valanginian diversity peak of 57 species (interval A) diversity decreases to 48 species (interval B) and increases subsequently to 60 species (intervals C \& D). It has to be kept in mind that the results for the intervals $\mathrm{B}$ and $\mathrm{D}$ may not be representative due to the low number of samples investigated from those sections (interval B, 9 samples). A general increase of diversity throughout the Late Valanginian is, however, observable. Diversity of agglutinated foraminifera is fairly 


\section{Klein \& J. Mutterlose}

constant throughout the Late Valanginian. Since the latter are more sensitive to environmental change, decreases of diversity indicate trends towards more restricted conditions. Variation of diversity is mainly caused by the diversity fluctuations of the calcareous foraminifera. The diversity of calcareous foraminifera is, in each section, higher than the diversity of agglutinated foraminifera. Most of the calcareous taxa can be included in the Nodosariidae, with common Lenticulina spp. and rarer Astacolus spp. and Laevidentalina spp. According to these data, interval A reflects rather suitable bottom water conditions, interval B impoverishment and intervals C \& D rather stable bottom water conditions. Most abundant are agglutinated foraminifera, with the only common calcareous species being Epistomina spp. Highest abundances of benthic foraminifera are observed in interval B, showing a clearly negative correlation with diversity. From the observation that low diversity accompanies high abundances it may be deduced that the assemblages of interval B reflect a primary ecological signal. This indicates R-mode selection, which reflects unstable, rather stressful, palaeoecological conditions. Short-term floods of Epistomina spp. occur in all four intervals. Interval $\mathrm{A}$ is characterized by four distinctive floods of E. caracolla, interval B by an $E$. caracollalE. ornata flood while interval $\mathrm{C}$ yields common $E$. caracolla throughout the sequence and interval D yet another $E$. caracolla flood. These floods are always restricted to intervals of 20-50 m thickness, reflecting a period of 4000-10 000 years (1 m/22 000 years; $200 \mathrm{~m} / 4.5 \mathrm{Ma})$.

The most common taxa, which include Ammobaculites spp., A. cellensis, Bulbobaculites spp., P. difflugiformis, $P$. fusca, $R$. indivisa and $R$. scorpiurus, represent $70-90 \%$ of the abundance. These agglutinated taxa may be viewed as ecologically robust forms.

High abundances of Reophax, Rhizammina and Haplophragmoides, which have been interpreted as a proxy of a restricted basin biofacies (King et al., 1989), were observed in intervals A \& B of the early Late Valanginian. This correlates positively with low diversity and high abundances of certain agglutinated taxa in these lowermost intervals. The overall pattern may be best explained by a slow, stepwise recolonization of the NWGB in Valanginian times after non-marine conditions prevailed in Berriasian times. Marine biota began to spread into the basin in earliest Valanginian times from the northwest via the Netherlands. It is also, at this time, that the Carpathian seaway via Poland opened towards the Tethys. The increase in diversity and the changes in the abundance patterns in Late Valanginian times may be evidence of increasing oxygenation and improved living conditions for foraminifera, as well as rising sea-level. This trend of a general improvement of ecological conditions throughout the Late Valanginian is based on the high diversity patterns in interval A.

The early Late Valanginian $P$. hollwedensis zone, is characterized by high diversity and the occurrence of the tethyanderived foraminifera species $C$. subhercynica. The genus Cerobertinella, established by Mjatliuk (1980), was previously only known from the Aptian and Albian of the Tethys (Kazakhstan). C. subhercynica has been described by Vespermann (1998) from the Upper Barremian of the Braunschweig area. These records of $C$. subhercynica coincide with a short-term influx of tethyan-derived ammonites into the
Boreal Realm. Kemper et al. (1981) described the tethyan ammonite taxa Saynoceras verrucosum, Karakaschiceras spp., Neohoploceras aff. Karakaschiceras spp., Valanginites spp., Bochianites sp. which migrated into the Boreal Realm during a sea-level highstand. It is from the same interval that a Boreal nannofossil excursion has been observed from sections of Tethyan affinities in Romania (Melinte \& Mutterlose, in press). It is only in this particular interval that Boreal taxa (ammonites, nannofossils) migrated into the Tethys, which clearly correlates with the emigration of tethyan taxa out of the Tethyan area. It seems unlikely that the simultaneous emigration of tethyan taxa into the Boreal Realm and the immigration of Boreal taxa into the Tethys is controlled by climate. These migration patterns and shifts in the composition of marine faunas and floras in the early Late Valanginian may be best explained by a global sea-level rise and related changes in the palaeogeographical framework. It is the sea-level highstand of the early Late Valanginian Saynoceras verrucosum ammonite Zone, which allowed an exchange of ammonites in both directions. The gradual sea-level rise in Late Valanginan times may be viewed as the driving factor in the short-term exchange of faunas. The early Late Valanginian sea-level highstand is known from many different areas (e.g., France, Germany) and has been identified as a 3 rd order sea-level highstand.

\section{CONCLUSIONS}

The distribution pattern of benthic foraminifera of the NWGB is controlled by distinctive palaeoenvironmental signals on different scales. Abundance and diversity patterns, negatively correlated to each other, clearly reflect a regional long term trend throughout the Late Valanginian (Fig. 8). The ecological conditions improved only slowly in this epicontinental sea, over a period of approximately 2 million years, indicated by a gradual recolonization of the formerly non-marine semirestricted basin. This is supported by diversity patterns throughout Valanginian and Hauterivian times. Similar patterns of a gradual improvement throughout the Valanginian of the NWGB has been demonstrated for calcareous nannofossils.

Short-term sea-level-controlled signals are superimposed on the long-term trends. The early Late Valanginian sea-level highstand, which is well known from ammonites (e.g., Rawson, 1999) and calcareous nannofossils (Melinte \& Mutterlose, in press) is also indicated by benthic foraminifera. Foraminiferal diversity is high during this period and tethyan taxa $(C$. subhercynica) do occur in this interval, which probably corresponds to a maximum flooding surface in a sequence stratigraphic context. This immigration of tethyan benthic species is a clearly short-term sea-level-related event on the order of half an ammonite zone (c. 200000 years). Various acmes of Epistomina spp., occurring throughout the Valanginian, may be viewed as short term fluctuations of benthic foraminifera. Each interval investigated yielded at least one of these Epistomina floods. For interval A, which covers slightly less than one complete ammonite zone (=400 000 years), four short Epistomina spp. floods were observed. Each of these is restricted to a few consecutive samples ( $3 \mathrm{~m}$ of sediment), individual floods are separated by 5 $-8 \mathrm{~m}$ thick intervals, with only rare Epistomina. 
Thus the acmes occur on a scale of approximately 100000 years, which is on the Milankovitch scale.

\section{ACKNOWLEDGEMENTS}

We acknowledge financial support by the Deutsche Forschungsgemeinschaft ( $\mathrm{Mu}$ 667/14-1, 14-2.). Michael A. Kaminski made many valuable additions and helped improve an earlier version of the manuscript. We thank Helmut Bartenstein and Jürgen Vespermann for critical comments on the taxonomy. Malcolm Hart, Peter Rawson and another reviewer improved the final version of the manuscript by providing constructive comments.

\section{Manuscript received 10 October 2000 Manuscript accepted 26 February 2001}

\section{REFERENCES}

Bartenstein, H. \& Bettenstaedt, F. 1962. Marine Unterkreide (Boreal und Tethys). In Arbeitskreis deutscher Mikropaläontologen, (Ed.), Leitfossilien der Mikropaläontologie, 225-297. Gebrüder Bornträger, Berlin.

Bartenstein, H. \& Brand, E. 1951. Mikropaläontologische Untersuchungen zur Stratigraphie des nordwestdeutschen Valendis. Abhandlungen der Senckenbergischen Naturforschenden Gesellschaft, 485: 239-336.

Brolsma, M. J. 1978. Benthic foraminifera. In Zachariasse, W. J., Riedel, W. R. \& Sanfilippo, A. et al. (Eds), Micropalaeontological counting methods and techniques. An exercise on a eight meters section of the Lower Pliocene of Capo Rossello, Sicily, 47-80. Utrecht Micropaleontological Bulletins, 17.

Jeletzky, J. A. \& Kemper, E. 1988. Comparative paleontology and stratigraphy of Valanginian Polyptychitinae and Simbirskitinae in Sverdrup Basin (Arctic Canada) and Lower Saxony Basin (Northwest Germany). Geological Survey of Canada Bulletin, 377, 355pp.

Kaminski, M. A., Boersma, A., Tyszka, J. \& Holbourn, A. E. L. 1995. Response of deep-water agglutinated foraminifera to dysoxic conditions in the Californian Borderland Basin. In Kaminski, M. A., Geroch, S. \& Gasinski, M. A. (Eds), Proceedings of the Fourth International Workshop on Agglutinated Foraminifera, 211-222. Grzybowski Foundation Special Publication no, 4.

Kemper, E. 1978. Einige neue biostratigraphisch bedeutsame Arten der Ammoniten-Gattung Dichotomites (NW-Deutschland, Obervalangin). Geologisches Jahrbuch, A45: 183-253.

Kemper, E. 1987. Die Bedeutung der Foraminiferen und Ostrakoden für die Klima Analyse der Kreide. In Kemper, E. (Ed.), Das Klima der Kreide-Zeit. Geologisches Jahrbuch, A96, 365-399.

Kemper, E., Rawson, P. F. \& Thieuloy, J.-P. 1981. Ammonites of Tethyan ancestry in the early Lower Cretaceous of north-west Europe. Palaeontology, 24: 251-311.

King, C., Bailey, H. W., Burton, C. A. \& King, A. D. 1989. Cretaceous of the North Sea. In Jenkins, D. G. \& Murray, J. W. (Eds),
Stratigraphical Atlas of Fossil Foraminifera (second edition), 372-417. Ellis Horwood, Chichester.

Loeblich, A. R. \& Tappan, H. 1987. Foraminiferal genera and their classification. Van Nostrand Reinhold, New York, 970pp.

Melinte, M. \& Mutterlose, J. in press. A Valanginian (Early Cretaceous) 'boreal nannoplankton excursion' in sections from Romania. Marine Micropalaeontology.

Meyn, H. \& Vespermann, J. 1994. Taxonomische Revision von Foraminiferen der Unterkreide SE-Niedersachsens nach Roemer (1839, 1841, 1842), Koch (1851) und Reuss (1863). Senckenbergiana Lethaea, 74: 49-272.

Michael, E. 1974. Zur Palökologie und Faunenführung im westlichen Bereich des norddeutschen Unterkreide-Meeres. Geologisches Jahrbuch, A19: 1-68.

Michael, E. 1979. Mediterrane Fauneneinflüsse in den borealen Unterkreide-Becken Europas, besonders Nordwestdeutschlands. In Wiedmann, J. (Ed.), Aspekte der Kreide Europas, 305-321. IUGS Series, A6.

Mjatliuk, E. V. 1980. Novyy Rannemelovoy rod Robertinid. [A new early Cretaceous robertinid genus]. In Azbel'A, Ya et al. (Ed.), Novye rody I vidy drevnikh rasteniy I bespozvonochnykh SSR, 109-110. [Vsesoyuznyy Neftyanoy Nauchno-issledovatel'skii Geologorazvedochnyy Institut (VNIGRI), Leningrad].

Murray, J. W. 1991. Ecology and palaeoecology of benthic foraminifera. John Wiley \& Sons Inc., New York, 397pp.

Mutterlose, J. 1992. Die Unterkreide-Aufschlüsse (Berrias-Hauterive) im nördlichen Wiehengebirgsvorland (N-Deutschland). Geologie und Paläontologie in Westfalen, 21: 39-113.

Mutterlose, J., Klein, C. \& Kessels, K. 2000. Die Floren- und Faunenführung des Ober-Valangin (Unter-Kreide) in NW Deutschland. Geologie und Paläontologie in Westfalen, 54: 1-95.

Niedziolka, 1988. Die Mikrofauna im Valangin-Hauterive-Grenzbereich des zentralen Niedersächsischen Beckens (Pollhagen, Wiedensahl II). Berliner Geowissenschaftliche Abhandlungen, A94: 89-173.

Rawson, P. F. 1999. Long-distance correlations in the ValanginianHauterivian: Argentinia-West Mediterranean-NW Europe. Scripta Geologica, Special Issue, 3: 151-158.

Rawson, P. F. \& Kemper, E. 1978. Varlheidites, n. gen. (Ammonoidea, Neocomitinae) aus dem Obervalangin NW-Deutschlands. Geologisches Jahrbuch, A45: 163-181.

Schott, W., Jaritz, W. \& Kockel, F. et al.1967/69. Paläogeographischer Atlas der Unterkreide von Nordwestdeutschland mit einer Übersichtsdarstellung des nördlichen Mitteleuropa, 306 Karten., 1 Tabelle; Hannover. Hierzu Erläuterungen zum Paläogeographischen Atlas der Unterkreide von NW-Deutschland, 315pp.

Seitz, O. 1950. Über die Gliederung des Ober- und Mittel-Valendis in Nordwestdeutschland. Zeitschrift der Deutschen Geologischen Gesellschaft, 101: 137-145.

Stadtler, A. 1998. Der Bentheimer Sandstein (Valangin, NW Deutschland). Eine palökologische und sequenzstratigraphische Analyse. Bochumer geologische und geotechnische. Arbeiten, 49: 1123.

Vespermann, J. 1998. Carlsiella brunsviga gen. nov., sp. nov. and Cerobertinella subhercynica sp. nov.: new foraminifera in the Upper Barremian of the eastern Lower Saxony Basin. Cretaceous Research, 19: 663-671. 


\section{APPENDIX A}

List of species cited in the text and figures, in alphabetical order by generic name.

\section{Agglutinated Foraminifera}

Ammobaculites agglutinans (d'Orbigny, 1846)

Ammobaculites eocretaceus Bartenstein \& Brand, 1951

Ammobaculites goodlandensis Cushmann \& Alexander,1930

Ammobaculites irregulariformis Bartenstein \& Brand, 1951

Ammodiscus gaultinus Berthelin, 1880

Ammodiscus tenuissimus (Gümbel, 1862)

Ammovertella cellensis Bartenstein \& Brand, 1951

Bulbobaculites inconstans erectum (Bartenstein \& Brand, 1951)

Bulbobaculites inconstans gracile (Bartenstein \& Brand, 1951)

Bulbobaculites inconstans inconstans (Bartenstein \& Brand, 1951)

Bulbobaculites subaequale (Mjatliuk, 1939)

Falsogaudryinella Bartenstein, 1977

Gaudryina vetustissima Bartenstein \& Brand, 1951

Gaudryinella hannoverana Bartenstein \& Brand, 1951

Glomospira gordialis (Jones \& Parker, 1860)

Haplophragmoides concavus (Chapman, 1892)

Haplophragmoides cushmani Loeblich \& Tappan, 1946

Proteonina difflugiformis Brady, 1879

Protomarssonella kummi (Zedler, 1961)

Psammospaera fusca Schulze, 1875

Reophax nodulosa Brady, 1879

Reophax scorpiurus Montfort, 1808

Rhizammina indivisa Brady, 1884

Tetraplasia quadrata Bartenstein \& Brand, 1951

Triplasia emslandensis emslandensis Bartenstein \& Brand, 1951

Triplasia Reuss, 1854

Trochammina depressa Lozo, 1944

Trochammina inflata (Montagu, 1808)

Trochammina squamata Jones \& Parker, 1860

Verneuilinoides inaequalis Bartenstein \& Brand, 1951

Verneuilinoides neocomiensis (Mjatliuk, 1939)

Webbinella subhemisphaerica Franke, 1936

\section{Calcareous Foraminifera}

Astacolus bronni (Roemer, 1841)

Astacolus calliopsis (Reuss, 1863)

Astacolus exilis (Reuss, 1863)

Astacolus humilis (Reuss, 1863)

Astacolus linaris (Reuss, 1863)

Astacolus mutterlosei Bartenstein \& Malz, in press

Astacolus schloenbachi (Reuss, 1863)

Buliminella loeblichi Bartenstein \& Brand, 1951

Bullopara laevis (Sollas, 1877)

Cerobertinella subhercynica Vespermann, 1998

Citharina cristellarioides (Reuss, 1863)

Citharina discors discors (Koch, 1851)

Citharina harpa (Roemer, 1841)

Citharina krobothi Meyn \& Vespermann, 1994

Citharina sparsicostata (Reuss, 1863)
Conorbis valendisensis Bartenstein \& Brand, 1951

Epistomina caracolla (Roemer, 1841)

Epistomina ornata (Roemer, 1842)

Frondicularia concinna Koch, 1851

Frondicularia hastata Roemer, 1842

Frondicularia microdisca dichotomiana Bartenstein \& Brand, 1951

Frondicularia rehburgensis Bartenstein \& Brand, 1951

Globulina prisca Reuss, 1863

Hechtina praeantiqua Bartenstein \& Brand, 1949

Histopomphus cervicornis (Chapman, 1892)

Laevidentalina debilis (Berthelin, 1880)

Laevidentalina distincta (Reuss, 1860)

Laevidentalina legumen (Reuss, 1845)

Laevidentalina linearis (Roemer, 1841)

Laevidentalina nana (Reuss, 1863)

Laevidentalina serrata (Eichenberg, 1934)

Laevidentalina soluta (Reuss, 1851)

Laevidentalina terquemi (d'Orbigny, 1849)

Laevidentalina varians (Terquem, 1866)

Lagena apiculata neocomiana Bartenstein \& Brand, 1951

Lagena laevis (Montagu, 1803)

Lenticulina dunkeri (Reuss, 1863)

Lenticulina eichenbergi Bartenstein \& Brand, 1951

Lenticulina muensteri (Roemer, 1839)

Lenticulina nodosa (Reuss, 1863)

Lenticulina ouachensis Sigal, 1952

Lenticulina pulchella (Reuss, 1863)

Lenticulina roemeri (Reuss, 1863)

Lenticulina saxonica Bartenstein \& Brand, 1951

Lenticulina subalata (Reuss, 1854)

Lenticulina subangulata (Reuss, 1863)

Lenticulina subaperta (Reuss, 1863)

Marginulina pyramidalis (Koch, 1851)

Marginulinopsis ? gracilissima (Reuss, 1863)

Marginulinopsis jonesi (Reuss, 1863)

Marginulinopsis oldenburgensis (Bartenstein \& Brand, 1951)

Marginulinopsis striatocostata (Reuss, 1863)

Nodosaria loeblichae Ten Dam, 1948

Nodosaria regularis Terquem, 1862

Pseudonodosaria humilis (Roemer, 1841)

Psilocitharella costulata (Roemer, 1842)

Psilocitharella kochi kochi (Roemer, 1841)

Psilocitharella kochi prolaevis Meyn \& Vespermann, 1994

Pyramidulina paucicosta (Roemer, 1841)

Pyramidulina sceptrum (Reuss, 1863)

Pyrulina gutta d'Orbigny, 1826

Pyrulina longa Tappan, 1940

Ramulina laevis (Jones, 1875)

Saracenaria pyramidata (Reuss, 1863)

Saracenaria valanginiana (Bartenstein \& Brand, 1951)

Sprillina minima Schacko, 1892

Tristix acutangula (Reuss, 1863)

Tristix insignis (Reuss, 1863)

Vaginulinopsis reticulosa Ten Dam, 1946 
Valanginian benthic foraminifera

\section{APPENDIX B}

Foraminiferal distribution in the sections at Twiehausen and Hollwede

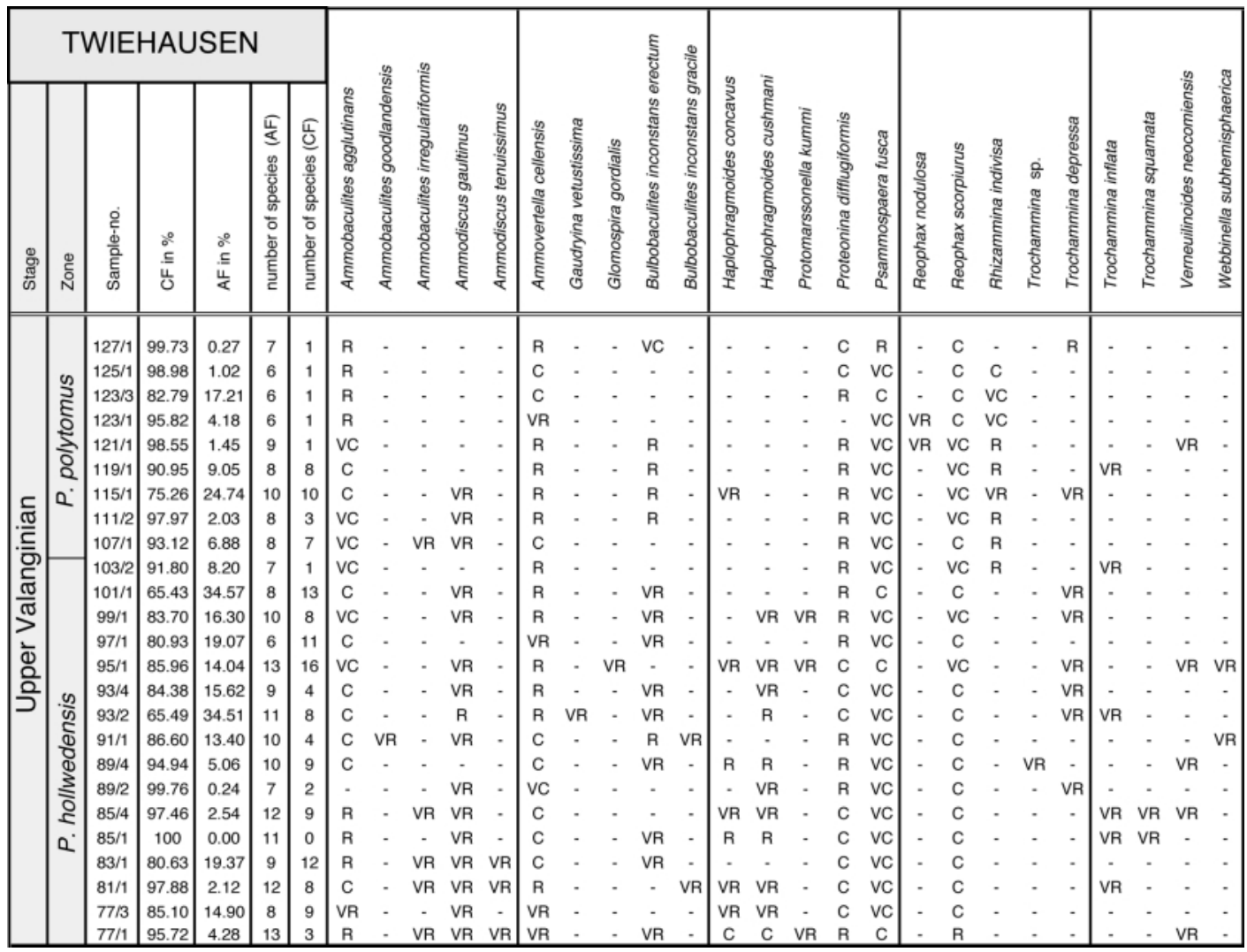

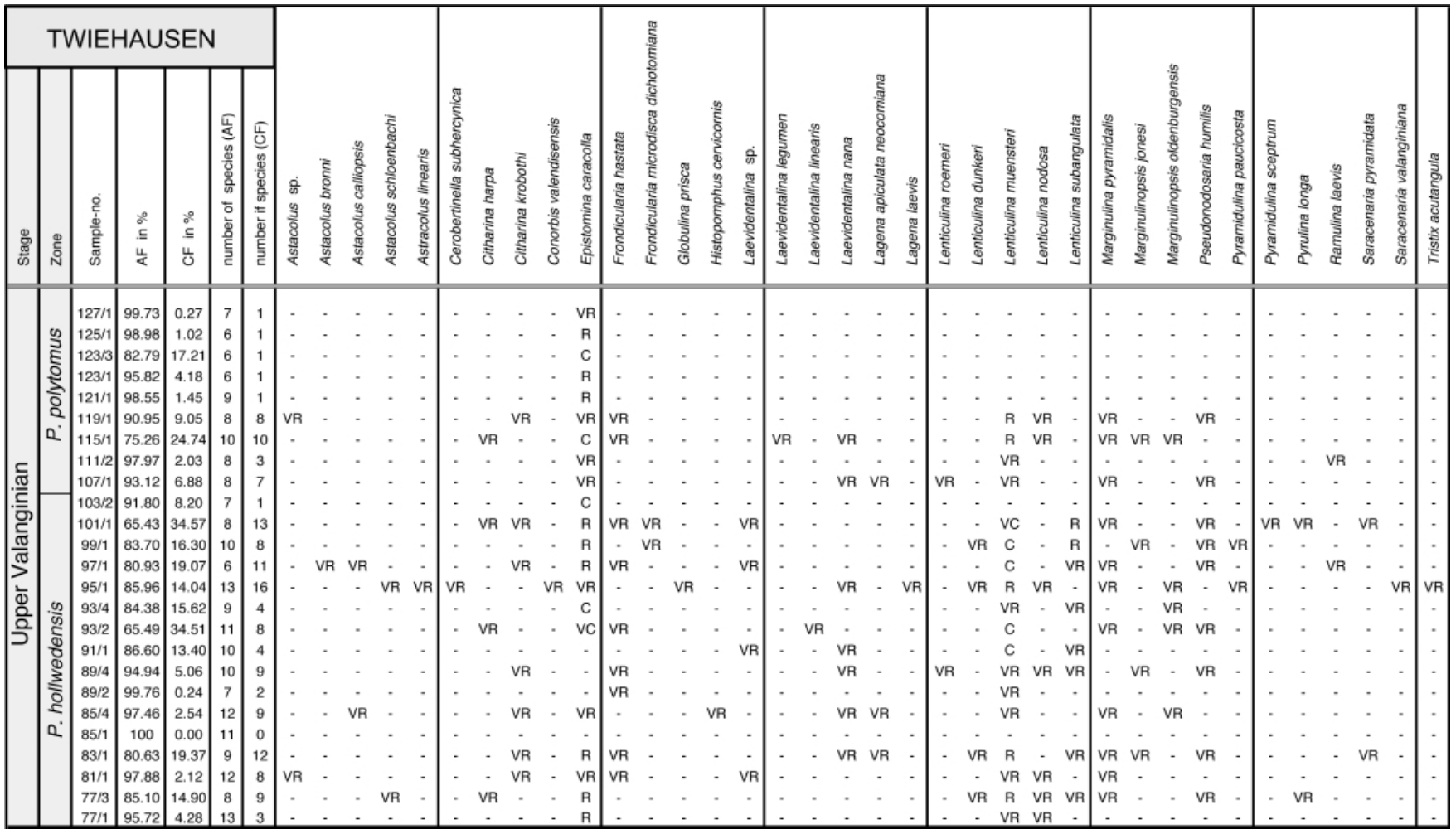


C. Klein \& J. Mutterlose

\begin{tabular}{|c|c|c|c|c|c|c|c|c|c|c|c|c|c|c|c|c|c|c|c|c|c|c|c|c|c|c|c|}
\hline \multicolumn{7}{|c|}{ HOLLWEDE } & \multirow[b]{2}{*}{ 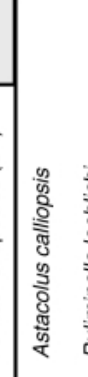 } & \multirow[b]{2}{*}{ 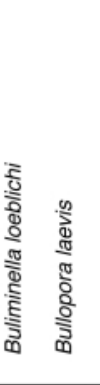 } & \multirow{2}{*}{\multicolumn{2}{|c|}{ 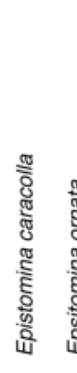 }} & \multirow[b]{2}{*}{ 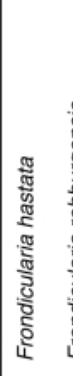 } & \multirow{2}{*}{\multicolumn{2}{|c|}{ 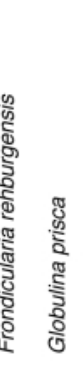 }} & \multirow[b]{2}{*}{ 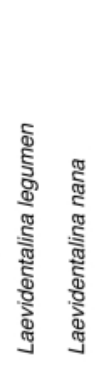 } & \multirow{2}{*}{\multicolumn{2}{|c|}{ 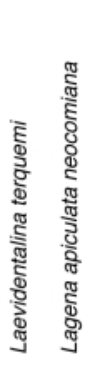 }} & \multirow[b]{2}{*}{ 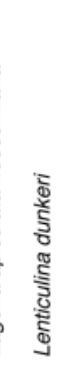 } & \multirow[b]{2}{*}{ 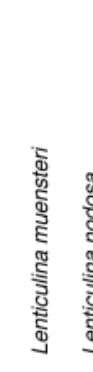 } & & \multirow[b]{2}{*}{ 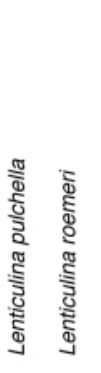 } & \multirow{2}{*}{\multicolumn{2}{|c|}{ 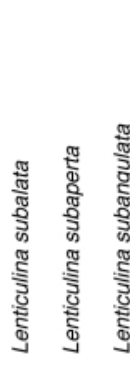 }} & \multirow{2}{*}{\multicolumn{2}{|c|}{ 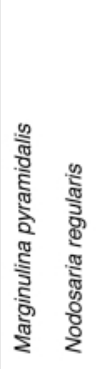 }} & \multirow[b]{2}{*}{ 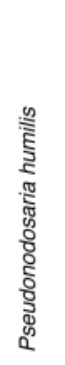 } & \multirow[b]{2}{*}{ 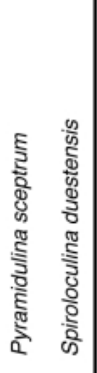 } & \multirow[b]{2}{*}{ 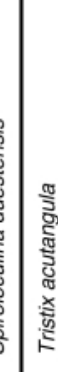 } \\
\hline $\begin{array}{l}\text { ఖँ } \\
\text { ஸे }\end{array}$ & $\begin{array}{l}\text { ڤ̆ } \\
\text { N. }\end{array}$ & 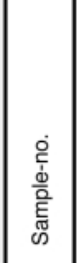 & $\begin{array}{l}\circ \\
\subseteq \\
\subseteq \\
\frac{\mathrm{L}}{\alpha}\end{array}$ & 总 & 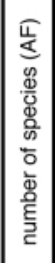 & 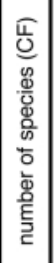 & & & & & & & & & & & & & & & & & & & & & \\
\hline 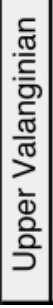 & 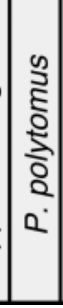 & \begin{tabular}{|l|}
$103 / 1$ \\
$101 / 1$ \\
$99 / 3$ \\
$99 / 2$ \\
$99 / 1$ \\
$97 / 2$ \\
$97 / 1$ \\
$95 / 2$ \\
$95 / 1$ \\
\end{tabular} & \begin{tabular}{|l}
83.00 \\
28.43 \\
99.21 \\
69.24 \\
15.94 \\
53.44 \\
92.35 \\
32.87 \\
95.91 \\
\end{tabular} & \begin{tabular}{|c|}
17.00 \\
71.57 \\
0.79 \\
30.76 \\
84.06 \\
46.56 \\
7.65 \\
67.13 \\
4.09 \\
\end{tabular} & \begin{tabular}{|l|}
13 \\
13 \\
16 \\
12 \\
10 \\
14 \\
15 \\
13 \\
12 \\
\end{tabular} & \begin{tabular}{|c|}
8 \\
11 \\
12 \\
12
\end{tabular} & $\begin{array}{cc}- & - \\
\text { VR } & - \\
- & - \\
- & - \\
- & \vdots \\
- & - \\
\text { VR } & \text { VR } \\
- & \text { VR } \\
\end{array}$ & 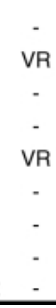 & $\begin{array}{c}\text { VC } \\
\text { VR } \\
C \\
\text { VC } \\
C \\
\text { R } \\
\text { VC } \\
\text { R } \\
\end{array}$ & $\begin{array}{c}\mathrm{C} \\
- \\
\mathrm{C} \\
\mathrm{VC} \\
\mathrm{C} \\
\mathrm{R} \\
\mathrm{VR} \\
-\end{array}$ & $\begin{array}{l}\text { VR } \\
\text { VR } \\
\text { VR } \\
\text { R } \\
\text { VR } \\
- \\
\text { VR } \\
\text { VR } \\
- \\
\end{array}$ & $\begin{array}{ll}- & 1 \\
- & V \\
- & \\
- & \\
- & 1 \\
- & 1 \\
- & V \\
- & \\
\text { VR }\end{array}$ & $\begin{array}{l}\text { VR } \\
- \\
\text { VR } \\
\text { VR } \\
\text { VR } \\
- \\
\end{array}$ & $\begin{array}{cc}- & \text { VR } \\
- & - \\
- & - \\
\text { VR } & - \\
- & - \\
- & - \\
& -\end{array}$ & \begin{tabular}{|c}
- \\
- \\
VR \\
\end{tabular} & $\begin{array}{c}- \\
- \\
- \\
- \\
- \\
\text { VR } \\
- \\
\text { VR } \\
\text { VR } \\
- \\
\end{array}$ & $\begin{array}{l}\text { VR } \\
\text { VR } \\
- \\
\text { VR } \\
\text { VR } \\
\text { VR } \\
\text { VR } \\
\text { VR } \\
- \\
\end{array}$ & $\begin{array}{c}\text { C } \\
\text { VC } \\
\text { VR } \\
\text { VR } \\
C \\
\text { C } \\
\text { VC } \\
\text { C } \\
\text { VR } \\
\text { VR } \\
\text { VR } \\
\text { VR }\end{array}$ & $\mathrm{v}$ & $\begin{array}{cc}- & \text { VR } \\
- & \text { VR } \\
- & - \\
- & - \\
- & - \\
- & \text { VR } \\
\text { VR } & \text { VR } \\
- & - \\
- & \text { VR } \\
\end{array}$ & $\begin{array}{ll}\text { VR } & - \\
- & - \\
- & - \\
- & - \\
- & - \\
- & \text { V } \\
- & - \\
- & - \\
- & -\end{array}$ & $\begin{array}{cc}- & V R \\
- & V R \\
- & - \\
- & V R \\
- & V R \\
V R & V R \\
- & V R \\
- & - \\
- & V R \\
\end{array}$ & $\begin{array}{cc}\text { VR } & \text { VF } \\
- & - \\
\text { VR } & - \\
- & - \\
- & - \\
- & \text { VF } \\
- & - \\
- & -\end{array}$ & $\begin{array}{cc}- & \text { VR } \\
R & \text { VR } \\
- & - \\
- & \text { VR } \\
- & \text { VR } \\
- & \text { VR } \\
R & \text { VR } \\
- & - \\
- & -\end{array}$ & $\begin{array}{lc}R & - \\
R & - \\
R & - \\
R & - \\
R & - \\
R & V R \\
R & - \\
- & - \\
- & -\end{array}$ & $\begin{array}{c}- \\
- \\
- \\
- \\
\\
\\
\text { RR } \\
- \\
-\end{array}$ & $\begin{array}{c}\text { VR } \\
- \\
-\end{array}$ \\
\hline
\end{tabular}

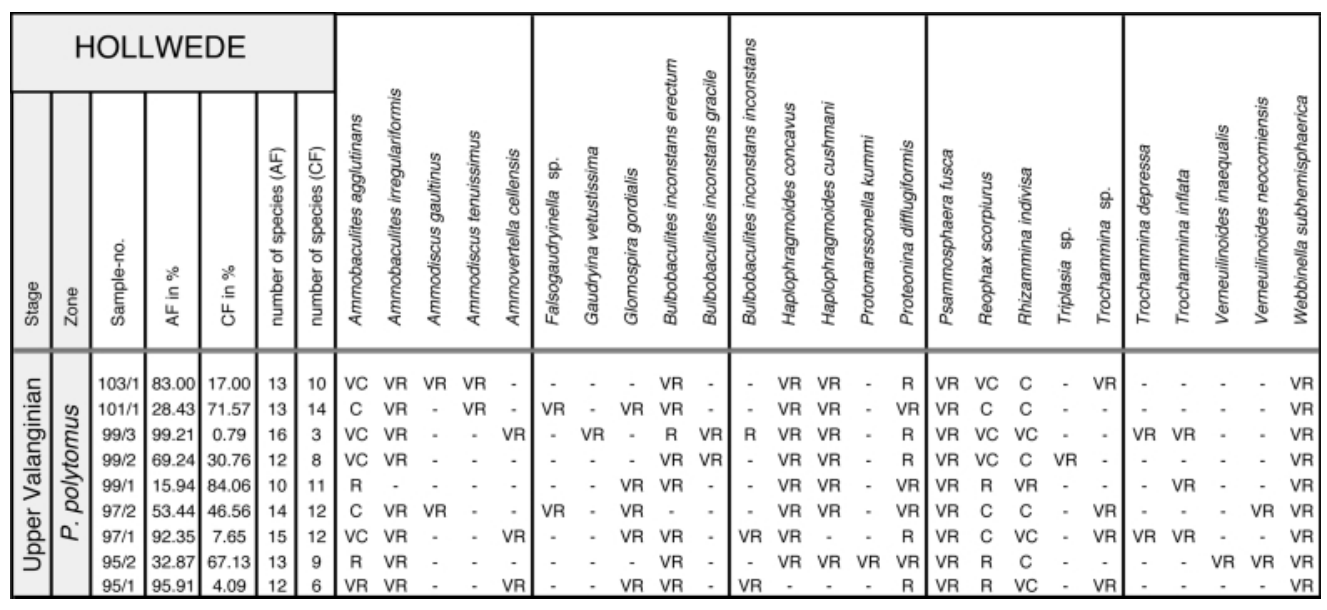

Foraminiferal distribution in the sections at Varlheide and Diepenau

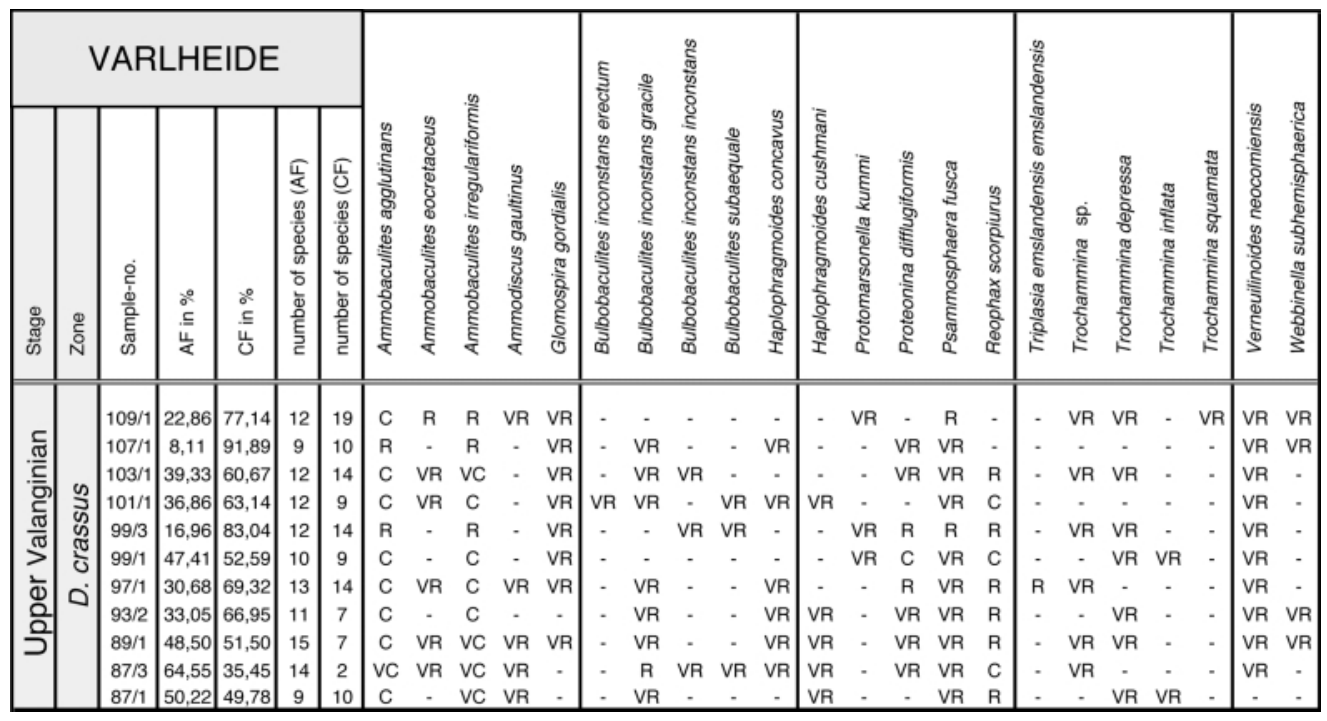


Valanginian benthic foraminifera

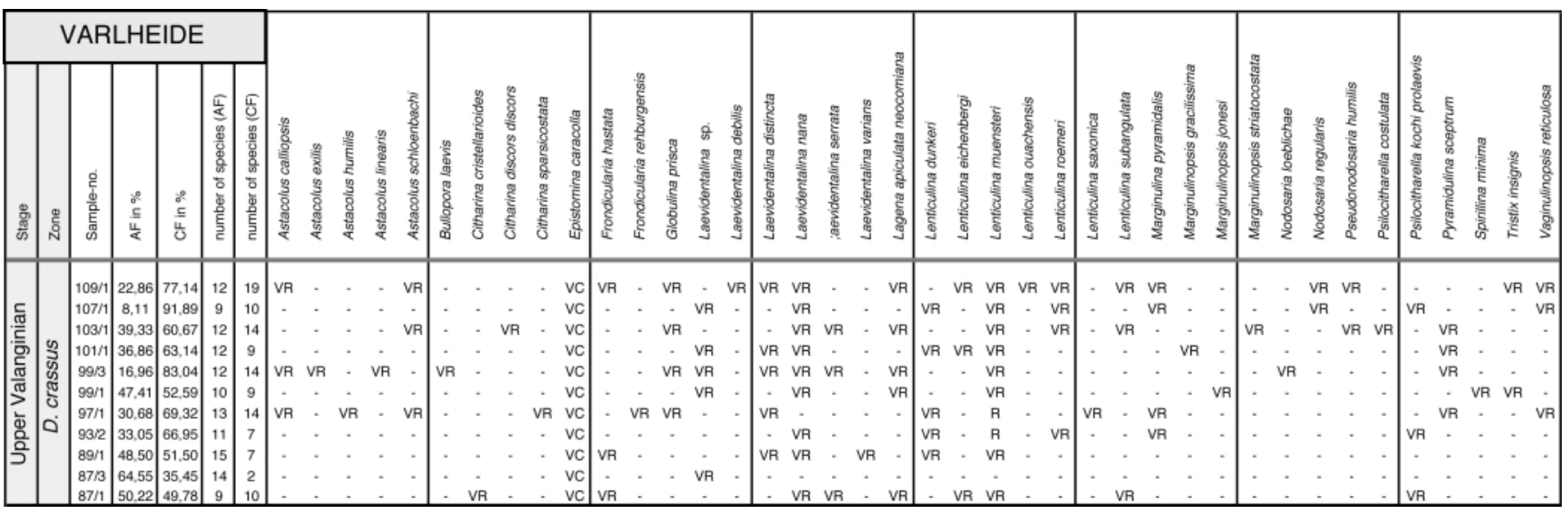

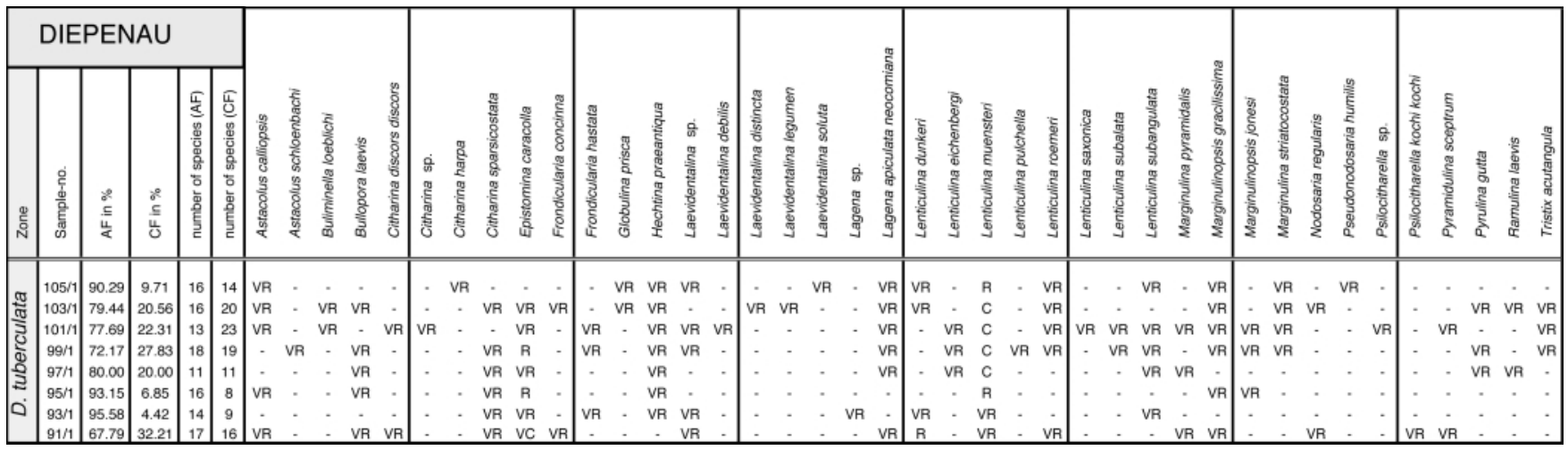

\begin{tabular}{|c|c|c|c|c|c|c|c|c|c|c|c|c|c|c|c|c|c|c|c|c|c|c|c|c|c|c|c|c|c|c|}
\hline \multicolumn{7}{|c|}{ DIEPENAU } & \multirow[b]{2}{*}{ 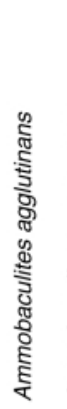 } & \multirow[b]{2}{*}{ 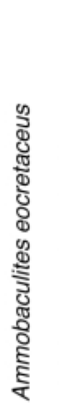 } & \multirow[b]{2}{*}{ 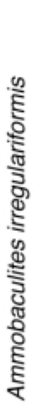 } & \multirow[b]{2}{*}{ 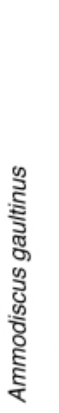 } & \multirow[b]{2}{*}{ 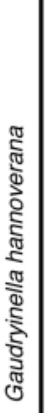 } & \multirow[b]{2}{*}{ 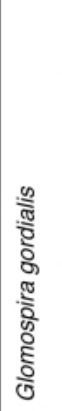 } & \multirow[b]{2}{*}{ 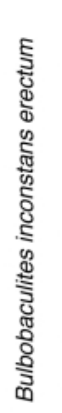 } & \multirow[b]{2}{*}{ 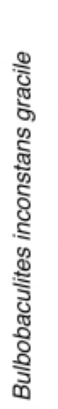 } & \multirow[b]{2}{*}{ 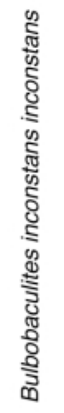 } & \multirow[b]{2}{*}{ 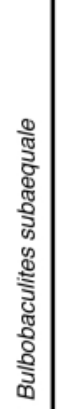 } & \multirow[b]{2}{*}{ 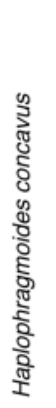 } & \multirow[b]{2}{*}{ 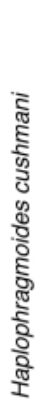 } & \multirow[b]{2}{*}{ 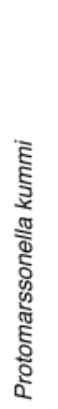 } & \multirow[b]{2}{*}{ 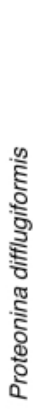 } & \multirow[b]{2}{*}{ 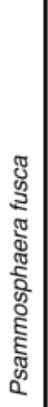 } & \multirow[b]{2}{*}{ 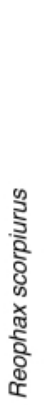 } & \multirow{2}{*}{\multicolumn{2}{|c|}{ 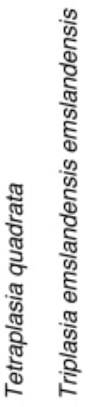 }} & \multirow{2}{*}{\multicolumn{2}{|c|}{ 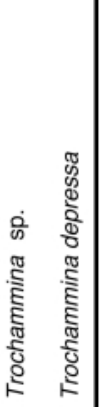 }} & \multirow{2}{*}{\multicolumn{2}{|c|}{ 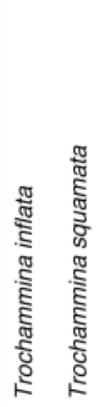 }} & \multirow[b]{2}{*}{ 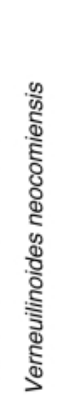 } & \multirow[b]{2}{*}{ 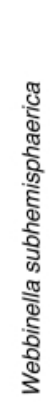 } \\
\hline $\begin{array}{l}\Phi \\
\text { के }\end{array}$ & $\stackrel{9}{\stackrel{\circ}{~}}$ & 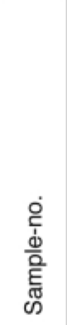 & $\begin{array}{l}\stackrel{\circ}{\circ} \\
\stackrel{5}{\longleftarrow} \\
\stackrel{\leftarrow}{\leftarrow}\end{array}$ & $\begin{array}{l}\stackrel{\circ}{\leftrightarrows} \\
\stackrel{5}{u}\end{array}$ & 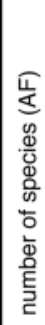 & $\begin{array}{l}\frac{\pi}{0} \\
\frac{0}{0} \\
\frac{0}{0} \\
\Phi \\
\frac{0}{0} \\
\frac{0}{0} \\
\Phi \\
\text { हे } \\
\text { है }\end{array}$ & & & & & & & & & & & & & & & & & & & & & & & & \\
\hline \multirow{4}{*}{ 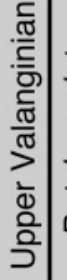 } & \multirow{4}{*}{ 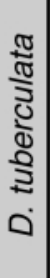 } & $5 / 1$ & 90.29 & 9.71 & 16 & 14 & C & R & VC & VR & VR & VR & VR & VR & - & C & R & $R$ & $R$ & & & & & & & & & & & \\
\hline & & $103 / 1$ & 79.44 & 20.56 & 16 & 20 & C & VR & VC & - & VR & VR & - & VR & - & R & R & $\mathrm{R}$ & VR & VR & - & R & - & - & VR & - & VR & - & VR & VR \\
\hline & & $93 / 1$ & 95.58 & 4.42 & 14 & 9 & C & $R$ & VC & . & VR & VR & - & VR & VR & C & VR & VR & - & - & - & R & - & - & - & VR & - & - & VR & VR \\
\hline & & $91 / 1$ & 67.79 & 32.21 & 17 & 16 & C & VR & VC & VR & & VR & - & $\mathrm{R}$ & VR & $\mathrm{R}$ & VR & VR & VR & - & & $\mathrm{R}$ & - & - & VR & & VR & VR & VR & VR \\
\hline
\end{tabular}

